\title{
Stierne mellem danske og tyske groede til
}

\author{
De sønderjyske gymnasieskoler i nazismens \\ skygge 1933-1945
}

\author{
af KAJ SØRENSEN
}

Ved ordningen af de fire sønderjyske gymnasieskoler 1918-1920 lagde man i centraladministrationen i Kobenhavn stor vægt på forsoning med det tyske mindretal og på respekt for andres synspunkter. Imødekommenhed over for det tyske mindretal blev et nogleord i skolepolitikken efter 1920. Men med nazismens indtog i Nordslesvig efter 1933 kom forsonligheden under pres: Lærerne risikerede, at kritiske bemærkninger om nazismen blev opfanget af stikkere i klasserne, og nazister af både dansk og tysk sindelag iværksatte uforsonlige smædekampagner for at få kritiske lærere fjernet. Uforsonligheden blev kun skærpet efter besættelsen den 9. april 1940, og Undervisningsministeriet måtte som resten af den danske statsadministration fore forhandlings- og samarbejdspolitik ud fra princippet om at »bøje sig for det mindre onde for at undgå det større«.

I august/september 1920 åbnede de fire sønderjyske gymnasieskoler i Haderslev, Aabenraa, Sønderborg og Tønder, og mere end to års tilrettelæggelsesarbejde var dermed slut. Såvel centralt i Undervisningsministeriet som lokalt $i$ det nordslesvigske skoleudvalg var der blevet arbejdet energisk på at få skabt gode rammer for de nye skoler. Samarbejdet mellem ministerium og skoleudvalg havde til tider været anspændt, men der var dog enighed om de overordnede mål: at de nye gymnasieskoler skulle bygge på respekt for andres synspunkter på tværs af sprog og grænse, og at arbejdet skulle tage sit udspring $\mathrm{i}$ forsoning mellem dansk og tysk. ${ }^{1}$

»Lov om Oprettelse af Statsskoler i de sønderjydske Landsdele« af 30. juni 1920 afslørede ikke meget om ministeriets skolepolitik. I hvert fald ikke med hensyn til forholdet til hjemmetyskerne og det tyske mindretal. Anderledes med ministeriets instruks af 14. april 1920 til de fire nyvalgte rektorer. ${ }^{2}$ Heri blev det præciseret, at ministeriet lagde stor vægt på ordene om forsoning med tyskerne og om respekt 
for andres synspunkter. Ingen kunne efter gennemlæsning af instruksen være i tvivl om, at ministeriet ønskede en problemløsende samarbejdspolitik. ${ }^{3}$ En del tyske elever var f.eks. så langt fremme i deres skolegang, at et sprogskifte ville være urimeligt eller direkte uigennemførligt. Derfor skulle rektorerne sørge for, at disse elever fik mulighed for at fuldende deres skolegang på tysk og efter tysk undervisningsplan og helst med lærere rekrutteret fra det hidtidige tyske lærerpersonale. Det blev begyndelsen til de tyske afviklingsklasser, som blev oprettet ved alle fire gymnasieskoler i en treårig periode. Ministeriet pointerede, at rektorerne skulle sørge for, at alle elever $i$ afviklingsklasserne fik tilbudt frivillig undervisning i dansk. I stedet for at bruge tvang ønskede ministeriet altså at komme de tyskprægede elever i møde og fore dem over i det danske sprog via det tyske. Det var klogt gjort, og man undgik derved de sammenstød og den strid mellem mindretallets og flertallets sprog, som andre steder skabte så store problemer. ${ }^{4}$ De fire nye statsskoler blev hurtigt samlingssted både for dansksindede og for tysksindede familier. De mange elever fra tyskorienterede hjem blev betragtet som medborgere og ikke som fjender, og de fandt sig hurtigt til rette blandt deres danske kammerater, uden at det kom til alvorlige sammenstød. ${ }^{5}$

Op gennem 1920'erne herskede der stort set fred og ro inden for de fire gymnasieskolers mure. Men sammen med den store økonomiske krise i 1930 holdt de nazistiske idéer deres indtog. I begyndelsen forte disse ideer ikke til sammenstød mellem dansk- og tysksindede elever. Men Hitlers hurtigt voksende national-socialistiske tyske arbejderparti (NSDAP) blev naturligvis diskuteret, og mange elever fulgte den politiske situation med lige så stort engagement som de voksne. ${ }^{6}$

\section{Tonen skærpes 1933-1945}

Efter Hitlers udnævnelse til tysk rigskansler den 30. januar 1933 blev store dele af mindretallet hurtigt grebet af den nationalsocialistiske bevægelse, og tonen blev skærpet. Det fik modsætningen mellem dansksindede og tysksindede til at vokse. Eller som formanden for Sprogforeningen, bibliotekar Jakob Petersen, udtrykte det: "Stierne mellem danske og tyske groede til. $\ll^{7}$ Mistilliden mellem mennesker med forskelligt nationalt og politisk sindelag voksede, og angiveri blev almindeligt.

Det tyske mindretal udgjorde i tiden frem til $1945 \mathrm{ca} .15 \%$ af befolkningen i Sønderjylland. En liberal dansk mindretalspolitik havde 
gjort det muligt for mindretallet frit at opbygge dets egne politiske og kulturelle organisationer, og en del af disse førte an i nazificeringen af det tyske mindretal i Sonderjylland. En senere tid har undret sig over, at nazismen med alle dens urimeligheder og menneskefjendske træk kunne erobre størstedelen af Sønderjyllands tysksindede befolkning. Men som rektor for Aabenraa Statsskole 1941-1975, Georg Buchreitz, skrev engang i 1930'erne, så var "store dele af mindretallet ... ideologisk forudbestemt til at gå ad nazis vej« - ikke så meget på grund af Hitlers sammensurium af ideer som af udsigten til, at Det tredje Rige ville være i stand til at rive Nordslesvig fra Danmark igen. ${ }^{8}$ Mindretallet genkendte sig selv og sine krav i Hitlers parole: "Heim ins Reich «. ${ }^{9}$ Men det tyske mindretals højlydte fordringer og ikke mindst kravet om en grænseflytning mod nord anfægtede selve det danske livsgrundlag $\mathrm{i}$ landsdelen og fik både unge og ældre dansksindede sønderjyder til at reagere. ${ }^{10}$

De nationalsocialistiske aviser, både nord og syd for grænsen, drev igennem hele perioden uhindret en systematisk ophidselseskampagne mod de danske gymnasieskoler, ofte med trusler mod skolernes rektorer. Selv småting fandt vej til deres spalter og blev sat op med kæmpe overskrifter. De danske myndigheders og de dansksindede sønderjyders bekymring - og irritation - samlede sig navnlig om det hjemmetyske dagblad Nordschleswigsche Zeitung. Kort efter besættelsen, den 17. juli 1940, blev en ny spalte, »Unsere Stimme«, under redaktion af lærer Asmus Wilhelm Jürgensen, der skrev under pseudonymet »Asmus von der Heide«, præsenteret. Denne spalte indeholdt dagligt skarp kritik af danske forhold og voldsomme angreb både på danske institutioner og enkeltpersoner, tit i en sådan form, at artiklerne fra dansk side blev opfattet som en slags angiveri. ${ }^{11}$

Partifører for det tyske mindretals nazi-parti, Nationalsozialistiske deutsche Arbeiter-Partei Nordschleswig (NSDAP-N), Jens Møllers til tider meget provokerende og selvpromoverende optræden både i sidste del af 1930'erne og under besættelsen var hverken velset i Berlin eller hos besættelsesmagtens ledelse i København. Da Jens Møller blev medlem af Folketinget i 1939 som det tyske mindretals repræsentant, blev han i slutningen af maj samme år kaldt til samtale i Berlin. Her orienterede Werner Grundherr, legationsråd i Det tyske Udenrigsministeriums politiske afdeling for Skandinavien, ham om, at Føreren ønskede et fredeligt forhold til Danmark og bad Jens Møller dæmpe parolerne. Møller måtte heller ikke berøre grænsespørgsmålet, og hvis han optrådte 
for skarpt i Folketinget, så ville han skabe vanskeligheder for sig selv i det praktiske arbejde! Det ser dog ikke ud til, at Jens Møller forstod eller ville forstå - betydningen af disse råd. ${ }^{12}$

\section{Artiklen i The Times 1933}

Udenrigsministeriet holdt et vågent øje med situationen i grænselandet og gik ofte ind i sager, som egentlig horte under andre ministeriers arbejdsområde. Et eksempel herpå er sagen om en artikel i det berømte britiske dagblad The Times for den 2. september 1933. Artiklens forfatter gav indledningsvis udtryk for sin største respekt for Danmarks behandling af det tyske mindretal. Under et besøg i en sønderjysk statsskole et par dage tidligere havde det dog undret ham meget at se, at der i et klasselokale ligefrem hang billeder af rigspræsident Hindenburg og andre tyske helte, ligesom journalisten fandt det ejendommeligt, at man $\mathrm{i}$ undervisningen benyttede landkort, hvor begge grænser, både den nye og den gamle, var markeret, og uden angivelse af, at Nordslesvig faktisk hørte til Danmark. Udenrigsministeriet bad Undervisningsministeriet undersøge sagen. ${ }^{13}$ Alle fire statsskolers rektorer blev spurgt, om der i et af deres skolers klasselokaler skulle hænge et billede af den tyske rigspræsident eller andre tyskere, og om man i undervisningen benyttede kort som angivet $\mathrm{i}$ artiklen.

Rektorerne for Haderslev Katedralskole, Sønderborg Statsskole og Tønder Statsskole afviste øjeblikkelig blankt. Men på Aabenraa Statsskole viste en nøje gennemgang af skolens magasin, at der lå et gammelt billede af Hindenburg, ganske vist ikke som rigspræsident, men som feltmarskal. Med hensyn til skolens kortsamling var der enkelte kort, der viste de to grænser uden angivelse af tilhørsforhold, men rektor mente ikke, de blev benyttet. Han lovede dog snarest muligt at udskifte disse kort med mere tidssvarende kort.

Da rektorernes indberetninger yderligere viste, at ingen af de fire statsskoler på noget tidspunkt havde haft besøg af en engelsk journalist, henvendte Undervisningsministeriet sig til de sønderjyske amtsskoledirektioner og forhørte sig. Nogle uger senere kunne skoledirektøren for Tønder amt, Nicolai Svendsen, meddele Undervisningsministeriet, at den skandinaviske korrespondent ved The Times, Mr T.G. Barman, havde besøgt Sønderjylland i slutningen af august 1933, og at amtsskolekonsulenten havde vist ham skolerne i Rudbøl og Højer. 
Disse skoler havde den engelske gæst øjensynlig troet var statsskoler. Det var rigtigt, at der i et klasselokale i Højer skole fra gammel tid hang et billede af daværende generalfeltmarskal Hindenburg foruden nogle billeder, som forestillede scener fra Schillers Wilhelm Tell. Men Nic. Svendsen påpegede, at han selv intet havde at indvende mod billederne, idet der jo også hang billeder af f.eks. den danske konge og dronning. De omtalte kort var en gave fra Dansk Kultursamfund til grænseskolerne, og Nic. Svendsen mente ikke, at der var grund til at rejse nogen form for kritik af disse kort. Han tilføjede, at kun en yderst ensidigt indstillet journalist kunne præstere en artikel som den, der her var tale om. Herefter henlagde begge ministerier sagen. ${ }^{14}$

\section{Nationale problemer i gymnasieskolerne}

Den voksende mistillid mellem dansk- og tysksindede vandt også indpas på de sønderjyske gymnasieskoler. På lærerværelserne blev der forholdsvis frit diskuteret politik, uden at det førte til alvorlige sammenstød - dog med Sønderborg Statsskole som en undtagelse. Her var der nemlig nationale spændinger både blandt eleverne og i lærerkollegiet. ${ }^{15}$ Forholdet mellem lærere og elever blev på alle fire skoler kraftigt præget af den politiske situation, bl.a. fordi lærerne - i hvert fald i timerne - var forpligtede til ikke at vise deres nationale eller politiske sindelag og derfor ikke kunne tale helt frit til eleverne. Og enhver kan vel forestille sig, hvor konstrueret en undervisningssituation kan blive, hvis læreren ikke tør være sig selv fuldt ud af frygt for, at en af eleverne er stikker. ${ }^{16}$ Adskillige elever og lærere fandt dog siden hen i deres fritid sammen, først i studiekredse og i forskelligt agitationsarbejde og senere i modstandsbevægelsen. ${ }^{17}$

Efterhånden som den politiske situation spidsede til, var der lærere, som ikke i længden kunne tie, men som både på skrift og i tale offentligt gav udtryk for deres meninger om den politiske situation. Men det var absolut ikke risikofrit, for i Sønderjylland var lunten kortere end i det øvrige land, og bemærkninger, som andre steder i landet ville være blevet overhørt, kunne her få meget alvorlige følger.

\section{Lektor Viggo Rosent}

Den første blandt lærerne, som blev offer for angiveri, var lektor ved Aabenraa Statsskole Viggo Rosent. Han havde været ansat ved Aa- 


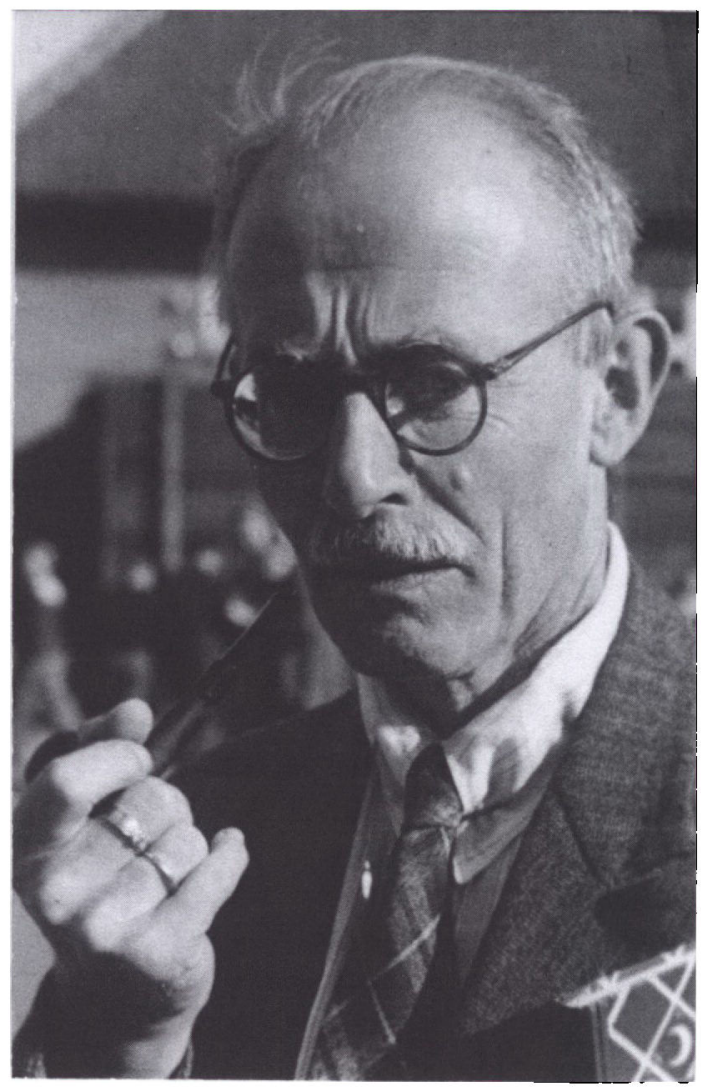

Viggo Rosent (1881-1946)

blev ansat ved Aabenraa

Statsskole ved Genforeningen $i$ 1920. Han lod $i$ efteråret 1938 en kritisk bemærkning om de tyske nazister falde $i$ en prizat sammenhang. Men bemærkningen blew hort af en tysksindet elev, der refererede den hjemme. I de folgende syv år udsatte det tyske mindretals ledelse Rosent for en veritabel smædekampagne, der kulminerede, da to SK-mand $i 1941$ blev beordret til korporligt at afstraffe den da 60-årige gymnasielektor. Foto: Abenraa Statsskole.

benraa Statsskole siden Genforeningen i 1920, først som adjunkt og siden 1929 som lektor. Han underviste desuden et par aftentimer om ugen på byens handelsskole. $\mathrm{Og}$ det var her, det gik galt. En tysksindet elev hørte sidst i september 1938 - efter undervisningens ophør - en kort ordveksling mellem Rosent og en af hans dansksindede elever. Rosent forsikrede siden hen på det kraftigste, at han havde troet, at han og den dansksindede elev, med hvem han ofte havde talt fortroligt, var alene i klassen. Ordvekslingen drejede sig om Hitlers radiotransmitterede tale $\mathrm{i}$ sportspaladset $\mathrm{i}$ Berlin aftenen før. Rosent udtalte om Hitler og hans nazistiske tilhængere, at man sandelig skulle tro, det var en flok gadedrenge! ${ }^{18}$

Den hjemmetyske elev refererede samtalen derhjemme, og forældrene orienterede kredslederen for NSDAP-N, gårdejer i Løjtkloster 
Jep Schmidt. Det var sandsynligvis ham, der lod bemærkningen gå videre til den tyske presse, som straks iværksatte en veritabel smædekampagne mod Viggo Rosent for at få ham fjernet fra grænselandet. Sideløbende blev Rosent igennem længere tid udsat for en række voldstrusler - i en sådan grad, at politiet fandt det nødvendigt at sætte hans hjem under bevogtning. ${ }^{19}$

Den 9. november 1938 - på den tyske nazismes vigtigste helligdag arrangerede NSDAP-N i Aabenraa en demonstrationsmarch, hvor man højlydt forlangte, at Viggo Rosent blev fjernet fra grænselandet. I en foromtale af demonstrationen i en tysk avis på selve dagen hed det: »Demonstrationstoget skal bl.a. ses som udtryk for tyskhedens oprør over den udtalelse om den tyske fører, der for omkring seks uger siden fremsattes af en af statsskolens lærere. (...). Til trods for energiske tyske fordringer om at fjerne den 'modige' herre fra grænseegnen, belaster den danske nation sig stadig med hans nærværelse. $\ll^{20}$

Da det efter Jep Schmidts mening åbenbart tog for lang tid at få Viggo Rosent fjernet fra Sønderjylland, skrev kredslederen direkte til undervisningsministeren. Brevet er trods alle høflighedsformularerne skrevet $i$ en nedladende tone og krydret med et par direkte trusler. Kredslederen påpegede, at NSDAP-N's ledelse længe havde holdt tilbage på de hede gemytter, fordi den mente, at det var ministeriet, der burde tale, "når en af dets embedsmænd for elever af begge lejre håner et venligsindet lands fører...« Kredslederen forventede derfor, at ministeren "vil finde en tilfredsstillende løsning, således at noget alvorligere undgås og roen i grænselandet ikke forstyrres ved måske endog nye processer $i$ retning af værn om den tyske ære ${ }^{21}$ Altså underforstået, at hvis Rosent ikke blev fjernet, så garanterede NSDAP-N's ledelse ikke for følgerne ... De »nye processer « henviser utvivlsomt til den samtidige, såkaldte »Stollig-affære«, der havde belastet det dansk-tyske forhold stærkt.

I Undervisningsministeriet overvejede man sagen og bad 21. december 1938 Viggo Rosent udarbejde en redegørelse om forløbet. Den lå klar på departementschef Fr. Graaes skrivebord den 27. december. Men en afgørelse lod vente på sig. De hjemmetyske nazister blev mere og mere utålmodige. Den 11. maj 1939 bragte den nyvalgte folketingsmand, partifører for NSDAP-N, dyrlæge Jens Møller, sagen op i Folketinget. Jens Møller nævnte i sin tale de mange »hadefulde angreb « på det tyske mindretal i Nordslesvig og fremdrog lektor Viggo Rosent som et eksempel herpå. Jens Møller spurgte undervisnings- 
ministeren, hvad han agtede at foretage sig i sagen, og om NSDAP$\mathrm{N}$ kunne forvente svar på sin henvendelse til ministeren. Undervisningsminister Jørgen Jørgensen svarede, at sagen var under overvejelse, og at en beslutning snarest ville blive truffet, hvorefter et svar ville blive givet til de folk, der havde sendt skrivelsen ind. ${ }^{22}$

I juli måned 1939 modtog Rosent endelig ministeriets afgørelse $\mathbf{i}$ sagen. Den ministerielle skrivelse må betegnes som en tjenstlig irettesættelse - om end af mildere art. Ministeriet beklagede Rosents udtalelser, og man bebrejdede ham, at han ikke forud for udtalelserne havde sikret sig, at der ikke var elever til stede, som kunne føle sig sårede over ordvalget. Ministeriet gik herefter ud fra, »at lignende tildragelser ikke vil finde sted fremtidig «. ${ }^{23}$ Det var en forholdsvis salomonisk løsning: Lektor Rosent fik en mild irettesættelse, som man håbede både ville skærpe hans forsigtighed og tilfredsstille hjemmetyskerne. For at gå ind på kravene om fjernelse ville være ensbetydende med, at lærere ved offentlige skoler i Sønderjylland i praksis skulle underkaste sig de samme betingelser for læreres ytringsfrihed, som gjaldt i Hitlers Tyskland. Og det hverken kunne eller ville man acceptere. Rosents brøde bestod jo trods alt også kun i en privat bemærkning, fremsat efter undervisningens ophør over for en elev, han havde tillid til - og ved en tilfældighed overhørt af en tysksindet elev.

Det tyske mindretal var stærkt utilfreds med ministeriets afgørelse, og den tyske presse besværede sig højlydt over de danske skolemyndigheders behandling af sagen. ${ }^{24}$ Undervisningsministeriet håbede dog, at sagen ville ebbe ud. Men det skete ikke. Ministeriet så sig derfor i foråret 1940 nødsaget til at tage sagen op igen og besluttede, at Viggo Rosent øjeblikkelig skulle søge orlov og midlertidig flytte fra Sønderjylland. Ministeriet ville, formentlig under indtryk af besættelsen, dog helst have ham væk permanent, og efter forhandling med undervisningsinspektøren for gymnasieskolerne fandt man en ledig stilling til ham i Struer pr. 1. august 1940.

Rosent havde stor respekt for de mennesker, der var højere placeret end ham selv. Således også for sine foresatte i ministeriet. Men når noget gik ham imod, eller hvis han følte, at nogen trådte ham for nær, kunne han være både hård og stejl. ${ }^{25}$ Så Rosent sagde nej tak! Han ville under ingen omstændigheder til Struer! Han ville ikke vige fra Sønderjylland, og hvis han absolut skulle væk, så ville han til København, hvor han havde familie. Nu tøvede embedsmændene i ministeriet, og efter en del diskussion internt føjede man Rosent. Til det 
tyske mindretals åbenlyse fortrydelse vendte han tilbage til Aabenraa og statsskolen i august $1940 .^{26}$

Det betød, at chikanerierne fortsatte. I marts 1941 blev Rosent endog korporligt overfaldet på gaden af to SK-mænd - medlemmer af den hjemmetyske kamporganisation Schleswigsche Kameradschaft - som stak ham adskillige lussinger og nogle nakkedrag. ${ }^{27}$ Det var ikke nogen spontan aktion: De to SK-folk, Christian Petersen og Emil Jacob von Essen, forklarede i 1946 under et forhør politiet i Aabenraa, at det var en overordnet inden for Schleswigsche Kameradschaft, lærer Otto Kortsch, der havde givet dem ordre til overfaldet. Læreren indrømmede at have givet ordre til at overfalde lektor Rosent, men påstod, at ordren oprindelig stammede fra kredslederen for NSDAP-N - Jep Schmidt fra Løjtkloster. Jep Schmidt indrømmede i Landsretten 15. februar 1949 - efter forst pure at have nægtet, - at det alligevel godt kunne være, at han på et tidspunkt havde fremsat nogle udtalelser, som kunne "opfattes som en ordre« til at give Viggo Rosent en afstraffelse. ${ }^{28}$

De to SK-mænd, Christian Petersen og Emil Jacob von Essen, blev den 12. december 1941 ved byretten idømt 40 dages hæfte for overfaldet. Dommen ophidsede NSDAP-Ns medlemmer og ikke mindst partifører Jens Møller stærkt. Men så greb den tyske konsul i Aabenraa, Ewald Lanwer, ind. Som repræsentant for Tysklands udenrigsministerium, Auswärtiges Amt, var konsulen ikke interesseret i episoder, der kunne belaste samarbejdspolitikken. Lanwer var bekymret over ikke blot Jens Møllers voldsomme reaktion på dommen, men også over den drejning, som sagen Rosent havde taget de sidste måneder, og han tog derfor en samtale med Jens Møller. Samtalens indhold refererede Lanwer i en indberetning til Det tyske Gesandtskab i København den 22. december 1941: Lanwer havde foreholdt Jens Møller dennes loyalitetserklæring i Folketinget, og havde med den største eftertrykkelighed udtalt, at det ikke var onskeligt, at sagen Rosent, der lå flere år tilbage, blev gjort til genstand for mere indgående drøftelser. Jens Møller havde erklæret sig villig til ikke foreløbig at rette flere angreb på Rosent i pressen, men havde dog bedt om, at sagen måtte blive forelagt for gesandtskabet, idet han ikke mente over for folkegruppen at kunne forsvare, at de to anklagede blev sat $\mathrm{i}$ fængsel, hvis ikke Rosent samtidig blev fjernet fra grænselandet. ${ }^{29}$

Legationssekretær i Det tyske Gesandtskab i København, Rolf Kassler, greb sagen pragmatisk an. Han henvendte sig $\mathrm{i}$ begyndelsen af januar 1942 personligt i Udenrigsministeriet og spurgte, om det ikke 
ville være muligt en passende tid at udskyde fuldbyrdelsen af dommen over de to SK-folk, der havde overfaldet lektor Rosent, til der i nogen grad var groet mos på sagen. Henvendelsen blev drøftet $\mathrm{i}$ Udenrigsministeriet på et par møder, hvor også udenrigsminister Erik Scavenius var til stede, men hverken ud fra et dansk eller tysk synspunkt anså ministeriet det for klogt at søge en udsættelse af strafafsoningen gennemført. Man gik dog ind på at undersøge muligheden for en udskydelse af strafafsoningen i en måned, såfremt det samtidig blev gjort klart for Det tyske Gesandtskab, at yderligere skridt i sagen ikke ville kunne komme i betragtning. ${ }^{30}$

Men der groede ikke mos på sagen. Dommen blev appelleret, og landsrettens stadfæstede den 8 . maj 1942 byrettens dom. Den 13. juni 1942 udtalte Udenrigsministeriet, at det intet havde at bemærke til, at afsoningen af den idømte straf blev iværksat, og kontorchef $i$ Udenrigsministeriet H.J. Hansen meddelte legationssekretær Kassler, at sagen jo nu måtte gå sin gang. En senere ansøgning om benådning blev afslået af Justitsministeriet, efter at alle instanser havde udtalt sig imod. ${ }^{31}$

I februar 1943 var der gået fire-et-halvt år, siden Rosents famøse bemærkning var faldet. Alligevel gjorde partifører Jens Møller bemærkningen til et vigtigt punkt i en meget aggressiv tale den 14. februar 1943 på et tysk partimøde i Haderslev, hvor de forsamlede hjemmetyskere i en efterfølgende resolution til stats- og udenrigsminister Erik Scavenius krævede strafforfølgelse af lektor Viggo Rosent og to navngivne præster (Schülein og Warncke) i grænselandet. I sin tale sagde Jens Møller bl.a., at han havde været til møder både i Kirke- og i Undervisningsministeriet, hvor han havde forlangt, at de tre nævnte personer øjeblikkelig blev straffet og derefter fjernet fra grænselandet. Både Kirkeministeren og Undervisningsministeren havde givet udtryk for forståelse for det tyske mindretals krav, men havde på den anden side begge påpeget, at de ikke på det foreliggende grundlag havde nogen lovmæssig hjemmel til at skride ind. Jens Møller fortsatte: "Det er en aldeles uholdbar situation, som vi simpelthen ikke vil finde os $i$. I fremtiden forlanger jeg af enhver SK-mand og af ethvert partimedlem, at han personligt stiller sådanne mennesker til regnskab, såfremt regeringen ikke skrider ind. « ${ }^{32}$ Det var faktisk en direkte ordre til partimedlemmerne om fremover at gribe til vold mod navngivne danske, hvis ikke de hjemmetyske krav blev imødekommet!

Et par dage efter partimødet i Haderslev talte kontorchef i Udenrigsministeriet H.J. Hansen med legationssekretær ved Det tyske Ge- 
Jens Nicolaisen Moller

(1894-1951) blev $i 1938$

"Fører « for det hiemme-

tyske nazi-parti NSDAP-

$N$. Hans voldsomme retorik var inspireret af de sydlige forbilleder. Jens Moller opfordrede fra talerstolen $p a$ et partimøde $i$ Haderslev den 14. marts 1943 »ethvert partimedlem " til personligt at stille de tre nazikritiske sønderjyder, lektor Viggo Rosent og præsterne Warncke og Schillein til regnskab, såfremt den danske regering ikke fjernede dem fra grænselandet. Jens Moller $i$ »talerpositur« ved et partimøde den 26. september 1943. Foto: Rudolf Gimm. Museum Sønderjylland. Institut for sonderjysk lokalhistorie.

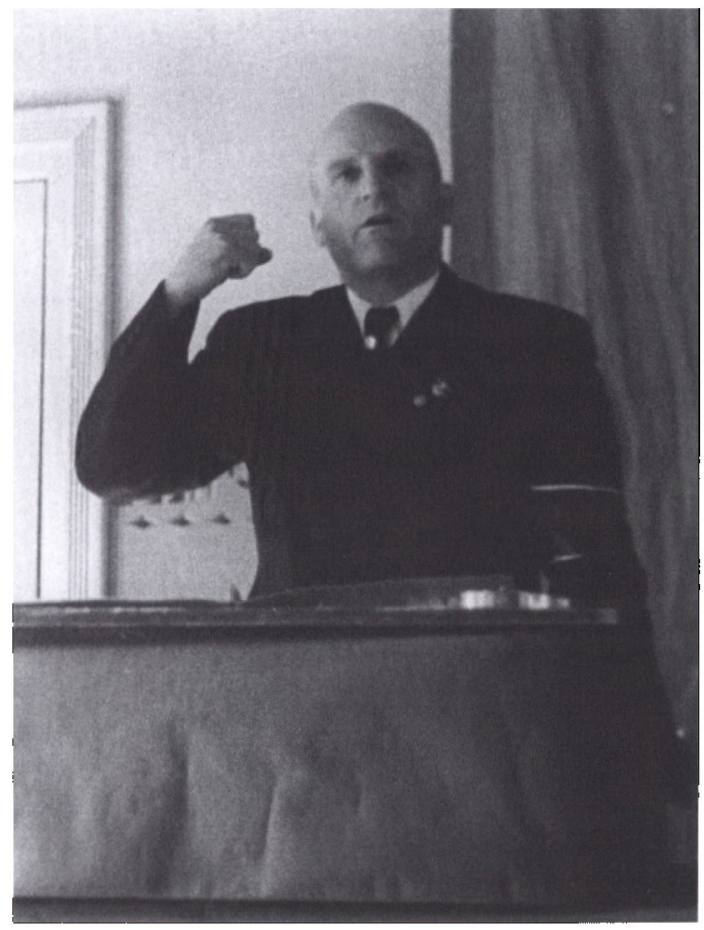

sandskab Rolf Kassler. Kassler var overrasket over, at Rosent var medtaget i resolutionen fra Haderslev, og han lod skinne igennem, at han hverken fandt det påkrævet eller klogt af Jens Møller at blive ved med at forulempe Rosent. Den 17. februar 1943 var partifører Jens Møller til møde med statsministeren i anledning af resolutionen. Under samtalen blev sagen Rosent også berørt, og Erik Scavenius pointerede, at han betragtede denne sag som henlagt. ${ }^{33}$ Det virkede tilsyneladende. Den 3. marts 1943 skrev Jens Møller til Udenrigsministeriet om de to præster Schülein og Warncke, som igennem længere tid havde påkaldt sig det tyske mindretals vrede. ${ }^{34}$ Men han bragte denne gang ikke Rosents navn på bane. ${ }^{35}$

I mellemtiden var embedsmændene i Undervisningsministeriet dog blevet nervøse. De besluttede endnu en gang at forflytte Rosent, både for at beskytte Rosent selv og for at komme det tyske mindretal i møde. Men Aabenraa Statsskoles rektor siden 1941, Georg Buchreitz, gik i forbøn for ham. Han skrev til ministeriet, at sagen i sig selv dog var så lille og nu så gammel, at den burde betragtes som forældet. Desuden havde 
han talt med Rosent, og denne var enig - og ville i øvrigt stadig meget nødig væk fra Sønderjylland. ${ }^{36} \mathrm{Og}$ ministeriet bøjede sig endnu engang: Rosent fik lov til at blive. Men Rosent vedblev at være skydeskive for det tyske mindretal under resten af besættelsen.

\section{9. april 1940}

Selv om man i slutningen af 1930'erne nok var forberedt på, hvad der kunne ske, og i den sidste tid før 9. april 1940 også på, hvad der ville ske, så kom den tyske besættelse af Danmark alligevel som et lammende chok for den danske befolkning i Sønderjylland - og som en glædelig overraskelse for det tyske mindretal. Den morgen fandtes der kun to grupper af mennesker i Sønderjylland: Nogle, der sørgede og harmedes, og andre, der glædede sig og jublede. Det dybe skel mellem de to nationale fronter holdt sig gennem hele besættelsestiden. ${ }^{37}$

Begivenhederne 9. april 1940 satte sig også dybe spor i de fire sønderjyske statsskolers liv. Aabenraa Statsskoles rektor, Ingvar Mogensen, blev tidligt om morgenen vækket af telefonen: En lærer ringede og spurgte, om der - den alvorlige situation taget i betragtning - var almindelig skoledag den dag. Først da erfarede rektor Mogensen, hvad der var sket. Rektor mente, at det fornuftigste ville være at forsøge at gennemføre en så normal skoledag som muligt. En del elever fra omegnen kunne dog ikke komme ind til byen, fordi tilkørselsvejene var spærrede af tyske transportkolonner. Der blev i de tidlige morgentimer kæmpet ved en af indfaldsvejene til Aabenraa, men kampen var forbi, før eleverne skulle hjemmefra. En elev var imidlertid gået ud for at kigge på kampene og mistede livet. Stemningen var derfor meget trykket, da rektor samlede de fremmødte elever og lærere til morgensang og morgenandagt. Han kunne intet andet sige end "Sort ser det ud, men almægtig er Gud «. Derefter blev der bedt for Danmark og sunget »Han som har hjulpet hidindtil, han hjælper nok herefter«. Det var en trist og trykket morgensamling, men præget af enhed og fællesfølelse. Klokken 11.00 samledes alle i festsalen, hvor de horte radiotransmissionen af kongens proklamation og statsminister Staunings meddelelse til det danske folk. Derefter gik alle hjem. ${ }^{38}$

Haderslev Katedralskoles rektor, A. Egeberg Jensen, var sygemeldt og indlagt på Kolding Sygehus, da tyske tropper gik over den danske grænse. Da han hørte om tyskernes besættelse af Danmark, forlangte han at blive udskrevet øjeblikkeligt og ilede hjem for at varetage sit em- 
bede. Ingen vidste jo, hvad morgendagen ville bringe. Den 10. april 1940 samlede han skolens elever og lærere til morgenandagt, og her talte han, mærket både af sygdom og af situationens alvor: "Det, der skete i går i vort land, må for alle danske stå som en forfærdende ulykke.« Han indprentede derefter både elever og lærere tre ting: For det første var det strengt forbudt at diskutere den politiske situation i timerne, og for det andet var det vigtigt, så snart som muligt at komme til at leve det daglige liv så normalt som muligt. Om den tredje ting sagde rektor: »Lad os prøve at holde modet og humøret oppe. Vi har længe levet trygt og godt i Danmark, mens andre led ondt, nu må vi bære vor part af verdens lidelser. Lad os ikke tabe modet for det. Det er mit indtryk, at de tyske invasionstropper i går optrådte med stor selvbeherskelse og ro og ikke udæskede. Lad os gøre vort til, at denne optræden ikke ændres, så kan den ulykke, som i første øjeblik syntes umulig at bære, dog måske blive tålelig «. Rektor sluttede: »Og husk så, at selv om natten er aldrig så mørk og lang, så kommer der igen en dag. Lad os i tålmod bære de byrder, der er lagt på os, og glæde os til den dag, der sikkert igen vil oprinde, da vort land atter er frit. $\ll^{39}$

Sønderborg Statsskoles rektor, A.J. West, blev kl. 7.30 ringet op af Jydske Tidende, som meddelte ham, at Danmark var blevet besat af tyskerne. Børnene fra Sønderborgs opland udeblev fra skole den dag, fordi buschaufførerne havde fået besked på ikke at tage børn med pga. fare for angreb fra tyskerne. Rektor afholdt morgensang kl. 8.00, fordi der var en del forvirring og uro blandt eleverne. Man sang først "Alt står i Guds Faderhånd « og "Der er et yndigt land «, og derefter talte rektor til de tilstedeværende elever og lærere, og man sluttede med at råbe tre gange hurra for Danmark. ${ }^{40}$

På Tønder Statsskole samlede rektor J. Randrup kl. 8.00 de tilstedeværende lærere på lærerværelset og meddelte, at der indtil videre skulle undervises som sædvanligt, skønt alle jo vidste, at intet ville blive "som sædvanligt". Telefonforbindelsen med København var afbrudt, så det var ikke muligt at komme i kontakt med Undervisningsministeriet, og der forlød på dette tidspunkt intet om kongens og regeringens holdning til tyskernes invasion. Derefter samlede rektor alle elever og lærere i festsalen, hvor man sang »Et kors det var det hårde, trange leje«. Så talte rektor kort, og man sluttede med at synge "Danmark i tusind år. « ${ }^{41} \mathrm{Om}$ 9. april 1940 skrev rektor $\mathrm{i}$ en indberetning til Undervisningsministeriet: "Tirsdag den 9. april var af 314 elever 56 fraværende, heraf antagelig ca. 20 på grund af sygdom og 6, 
fordi persontrafikken Padborg-Tinglev var indstillet. De øvrige - ca. 30 elever, hvoraf kun få var fra Tønder by - var ikke mødt, fordi forældrene var betænkelige ved at sende dem hjemmefra. ${ }^{\mathbf{4 2}}$

Videre fortæller rektor Randrup om den 9. april, at der om formiddagen kl. ca. $9.45 \mathrm{kom}$ to danske nationalsocialister ind på skolens grund og hejste det tyske flag på skolens flagstang. Rektor fik fat i de to unge mænd og spurgte med hvilken bemyndigelse, de gjorde det. De ville ikke besvare spørgsmålet, men den ene af dem sagde med et ondt blik i øjnene, at nu ville det tyske flag jo blive hejst på alle offentlige bygninger i Tønder. Da rektor gentog sit spørgsmål, henviste den unge mand til politimesteren, af hvem rektor efterfølgende fik at vide, at de overhovedet ingen bemyndigelse havde. Rektor tog derefter flaget ned, og der indtraf ikke senere på dagen flere af den slags begivenheder på skolen. Undervisningsministeriet skrev til rektor, at man karakteriserede flaghejsningen som drengestreger, og at han ikke skulle foretage sig yderligere i sagen. Flaget gemmes endnu den dag i dag på rektors kontor! ${ }^{43}$

\section{Undervisningsministeriets samarbejdspolitik 1940-1943}

Det danske skolevæsen kom forholdsvis uskadt gennem besættelsestiden. Det havde ikke mindst undervisningsinspektøren for gymnasieskolerne, A.C. Højberg Christensen, sin store andel i. Allerede i juni 1940 besluttede ministeriet, at alle forhandlinger med den tyske besættelsesmagt om danske skoleforhold skulle gå gennem ham. Højberg Christensen var mag.art. i tysk og dybt fortrolig med tysk sprog og kultur, og han havde nemt ved at gøre sine synspunkter gældende over for tyskerne. Ved dannelsen af regeringen Scavenius den 9. november 1942 afløste Højberg Christensen den radikale Jørgen Jørgensen som undervisningsminister. ${ }^{44}$ At han var fortrolig med tysk kultur betød ikke, at han var tyskvenlig. Med Højberg Christensen som forhandler med tyskerne var den danske skole fortsat på danske hænder. ${ }^{45}$ Embedet som undervisningsminister bestred han formelt kun til regeringens tilbagetræden den 29. august 1943, men reelt indtil 5. maj 1945. Politikerne var nemlig ikke sat ud af spillet efter regeringens tilbagetræden, men vedblev at virke $i$ det skjulte, og mange af ministrene opretholdt den daglige kontakt med deres ministerium. ${ }^{46}$

I besættelsestidens første år videreførte undervisningsminister Jørgen Jørgensen ministeriets hidtidige praksis med at søge personlig 
Axel Christen HøjbjergChristensen (1888-1972) var 1927-1958 undervisningsinspektor for gymnasieskolerne. Under besættelsen 1940-1945 lå han helt på regeringens samarbejdslinje. Hans mail var at holde skolerne og deres elever fri at antityske demonstrationer og sabotage. Han blev $i$ november 1942 undervisningsminister $i$ regeringen Erik Scavenius. Portretfoto af A.C. Hojberg-Christensen, sandsynligvis taget $i$ forbindelse med hans udnæonelse til undervisningsminister $i$ 1942. Det Kgl. Biblioteks Kort-og Billedsamling.

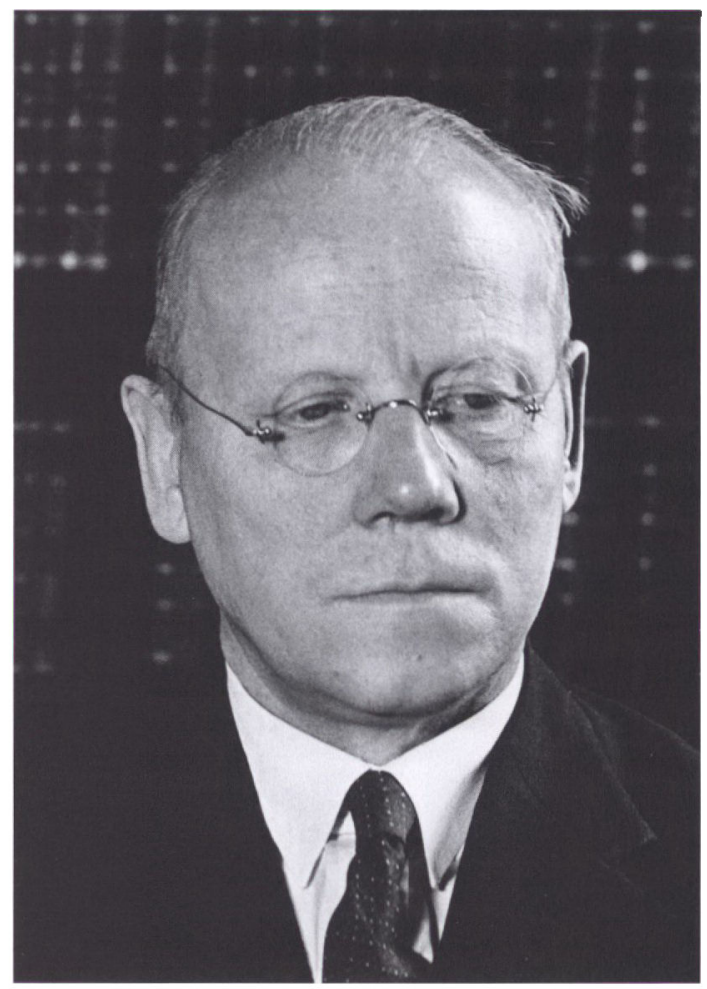

kontakt med rektorerne gennem afholdelse af rektormøder. Disse møder blev af stor betydning under besættelsen, fordi ministeren og ministeriets embedsmænd her blev holdt underrettet om forholdene ude på de enkelte skoler, og ministeren fik på møderne lejlighed til at redegøre for regeringens politik og give rektorerne direktiver. Kongens bud til det danske folk den 9. april 1940, hvor han pålagde alle danskere at optræde roligt og værdigt og undgå udæskende adfærd, gjaldt naturligvis også for skolerne, og det stadige omkvæd på ministerens taler på rektormøderne var derfor en indtrængende opfordring til ro og besindighed og at bøje sig for det mindre onde for at undgå det større. ${ }^{47}$ Dette var under hele besættelsen rettesnor for Undervisningsministeriets embedsmænd. Det overordnede politiske mål var at undgå det værst tænkelige og at bevare den danske skoles frihed uden indblanding fra den tyske besættelsesmagt. Skolernes forhold $i$ en del af de andre besatte lande var da også skræmmende 
eksempler på, hvor galt det kunne gå. I januar 1941 måtte det norske undervisningsministerium således udsende en forordning om, at elever i 3.g, som meldte sig til Regiment "Nordland ", kunne få afgangsbevis for bestået studentereksamen i sommeren 1941 uden at have deltaget $i$ undervisningen efter optagelsen $i$ regimentet og uden at have været til eksamen. ${ }^{48}$ Forordningen kom senere til også at gælde for studentereksamen i 1942 og $1943 .{ }^{49} \mathrm{Og}$ de nederlandske skoler blev i 1942 tvunget til at udsende et cirkulære om øjeblikkelig suspension af lærere, der gav udtryk for anti-tyske holdninger og derved "modvirkede en gunstig udvikling af det nederlandske skolevæsen. ${ }^{50}$ Men sådan gik det altså ikke i Danmark.

\section{Statsskolerne i begyndelsen af besættelsestiden}

I de sønderjyske gymnasieskolers årsskrifter og jubilæumsskrifter omtales de første år af besættelsestiden som stort set problemfri. Sammenlignet med årene 1944-45, hvor skolerne blev beslaglagt af tyskerne "til andet formål « (først og fremmest til indkvartering af flygtninge), så undervisningen måtte foregå rundt om i byerne, for det meste i mindre egnede lokaler, er det rigtigt. Kun én gang i besættelsesåret $1940 \mathrm{blev}$ en af de fire gymnasieskolers elever grebet i en sabotagehandling. Det var en elev på Tønder Statsskole, som i august 1940 blev taget $i$ at klippe en af det tyske militærs telefonledninger over. Det pudsige ved episoden var, at drengen kom fra et tysksindet hjem ${ }^{51}$

Hverdagen på de sønderjyske gymnasieskoler var dog også i begyndelsen præget af den tyske besættelse: Etablering af beskyttelsesrum, luftværnsforanstaltninger, afkortning af skoletiden i vintermånederne (for at undgå udgifter til mørklægning, blev der kun undervist, når det ikke var nødvendigt at tænde lys i klasserne), problemer med brændselstilførsel, så undervisningen af og til måtte foregå i kolde lokaler, og indkaldelse af lærere til militærtjeneste. Ud over den utryghed og spænding, som den politiske situation førte med sig, greb alle disse ting også forstyrrende ind $i$ undervisningen, og alle fire statsskoler var ude for periodevis beslaglæggelse af lokaler til troppeindkvarteringer, lazaretter o.a.

Midt i maj 1940 indberettede Tønder Statsskoles rektor til ministeriet, at det tyske militær den 19. maj havde indkvarteret 90 tyske soldater i skolens to gymnastiksale. Derudover havde militæret lagt beslag på systuen og et klasseværelse. Soldaterne kom nordfra og skulle videre 
sydpå, men man vidste ikke, hvor længe de ville blive. Tyskerne beordrede skolen til at sørge for mørklægning af de beslaglagte rum, og udgifterne hertil blev betalt af Tønder Kommune, der ligeledes sørgede for at dække udgifterne til ekstra rengøring i forbindelse med indkvarteringen. Den 28. maj 1940 rejste soldaterne, og rektor meddelte ministeriet, at undervisningen ikke i nævneværdig grad havde været generet af de tyske soldaters tilstedeværelse; dog med undtagelse af dagen før soldaternes afrejse, hvor de ikke alene havde lavet eksercits på skolens legeplads, men endog haft skydeøvelser med maskinpistol!

Der blev ikke i denne omgang tale om egentlige ødelæggelser af lokaler eller inventar, men vi ved fra andre skoler, som i 1940-1941 midlertidigt havde tyske soldater indkvarteret, at det kunne have ødelæggelser til følge. Undervisningsministeriet gjorde det $\mathrm{i}$ hvert fald klart, at der skulle udvises megen påpasselighed med, at besættelsesmagten i erstatningssager ikke kom til at betale for mere, end de havde ødelagt. ${ }^{52}$ I den sidste ende kom pengene jo via clearingkontoen fra den danske stat.

Aabenraa Statsskole fik ligeledes i foråret 1940 tyske soldater indkvarteret i begge skolens gymnastiksale. Men da soldaterne også her opførte sig korrekt og hensynsfuldt, og da beslaglæggelsen kun varede få dage, blev den heller ikke her i særlig grad til gene for undervisningen. Efter soldaternes afrejse blev der indrettet nødlazaret $\mathrm{i}$ den ene gymnastiksal. Lazarettets remedier blev imidlertid anbragt på gymnastiksalens loft, så salen foreløbig kunne bruges til gymnastikundervisning. ${ }^{53}$

\section{Dimissionstaler 1940}

Rektorernes taler til årets studenter årgang 1940 var naturligt nok praget af den politiske situation. Haderslev Katedralskoles rektor, A. Egeberg Jensen, kunne ikke love årets studenter en lys og tryg fremtid, men kun garantere for, at der forude lå en stor og vigtig opgave og ventede på dem: "Vi ved alle, at hvordan end afslutningen på krigen bliver, så vil det ikke være os muligt at fortsætte, hvor vi slap den 9. april. Hvem der end sejrer, vil verden få et nyt ansigt. En epoke er forbi, en ny skal påbegyndes. Kan jeg ikke i dag love jer velstand og en tryg fremtid, så kan jeg love jer - måske en meget svær opgave - men også den største og skønneste opgave, en ungdom kan få: at være med til at føre vort land ind i den nye tid. ${ }^{54}$ 
Aabenraa Statsskoles rektor, Ingvar Mogensen, slog i sin tale en meget mørk tone an og beklagede, at det, der skulle have været en fest, alligevel ikke kunne blive en fest, da det ikke var danskerne muligt på daværende tidspunkt at være glade, for end ikke i de mest pessimistiske øjeblikke havde nogen kunnet forestille sig, at en årsfest skulle fejres, mens krigsmaskiner brummede over skolens tage. Rektor opfordrede dimittenderne til ikke at give op, men trods sorgen og skammen bevare modet til genrejsning selv under trange kår. ${ }^{55}$

A.J. West, rektor for Sønderborg Statsskole, tog i sin tale til årets studenter udgangspunkt $\mathrm{i}$ begrebet frihed og omtalte det ejendommelige ved friheden: Når den bliver begrænset, så øges samtidig kærligheden til den. Så selv om verden stod i brand, og fremmede soldater havde besat landet, opfordrede rektor studenterne til »at tro på fremtiden, til at nære et lyst og levende håb om, at gamle Danmark skal bestå «. ${ }^{56}$

Mest interessant er den tale, som Tønder Statsskoles rektor, Jakob Randrup, holdt. Ikke så meget på grund af det, han sagde, men mere på grund af det, han ikke sagde! Rektor Randrup var nemlig en forsigtig mand. Selv om han var kraftig modstander af forhandlingspolitikken, ${ }^{57}$ så ville han dog nødig lægge sig ud med sine foresatte $\mathrm{i}$ ministeriet $\mathrm{i}$ København. Derfor gjorde han noget, som ingen af de andre sønderjyske rektorer gjorde: Han indsendte sin dimissionstale til Udenrigsministeriets Pressebureau, der under besættelsen administrerede den pressecensur, som var en følge af de tyske krav til Danmark, og spurgte, om det var i orden, at han sagde således ved årsafslutningen.

Det var det ikke! Pressebureauets kontorchef, Karl I. Eskelund, nøjedes ikke med at strege ud i manuskriptet, men anførte også, hvad Jakob Randrup skulle sige i stedet for: Han måtte overhovedet ikke bruge ordet "Genforeningen «. Han måtte heller ikke sige, at de små staters stilling over for stormagterne var et "sørgeligt aktuelt « problem, det var kun et aktuelt problem og ikke andet. Han måtte ikke sige, at engelsk og fransk ungdom atter kæmpede mod tysk ungdom, men han skulle sige, at "ungdom kæmpede mod ungdom«. Danske skibe blev ikke torpederet, men de stødte på miner. Der var heller ikke tyske soldater i Danmark, der var "fremmede" soldater i landet. Og kongens ansigt havde ikke på noget tidspunkt været præget af sorg, men var derimod "alvorligt «. 58 


\section{Rektorskifte i Aabenraa}

Den 21. april 1941 fyldte Aabenraa Statsskoles rektor Ingvar Mogensen 70 år og skulle derfor pr. 1. maj fratræde sin stilling og gå pension. På skolen fandt man imidlertid et rektorskifte direkte før skolens mange eksaminer og årsprøver meget uheldigt, og ministeriet efterkom skolens ønske om, at Mogensens pensionsdato blev udskudt til 1. august. ${ }^{59}$

Rektorstillingen blev opslået ledig den 2. maj, og ved ansøgningsfristen udløb var der indkommet 12 ansøgninger. ${ }^{60}$ Praksis var, at ministeriet straks ved ansøgningsfristens udløb sendte de indkomne ansøgninger til undervisningsinspektoren for gymnasieskolerne, som havde udtale- og indstillingsret. Undervisningsinspektøren skrev dernæst en udtalelse om hver enkelt ansøgers menneskelige, faglige og pædagogiske kvalifikationer, udtalte sig om ansøgernes egnethed som rektor og indstillede den efter hans mening bedst egnede. Sådan var proceduren også ved besættelsen af rektoratet i Aabenraa i 1941. ${ }^{61}$ Men embedsmændene i ministeriet valgte en anden. Det var ganske vist set før, men det interessante er, at ministeriet udmærket var klar over, at udnævnelsen af adjunkt Georg Buchreitz til rektor for Aabenraa Statsskole ville falde tyskerne alvorligt for brystet. Men det tog ministeriet altså ikke hensyn til. ${ }^{62}$

Georg Buchreitz havde fra 1930 og tre år frem været ansat som adjunkt i fagene dansk og historie ved det nyoprettede tyske gymnasium i Aabenraa. Indtil begyndelsen af 1933 havde der hersket et venskabeligt forhold mellem Buchreitz og hans kolleger. Men derefter ændrede næsten alle deres holdning til ham, uden at der dog på nogen måde var tale om åben konflikt. Buchreitz blev frosset ud, angiveligt på grund af udtalelser imod det nationalsocialistiske Tyskland. ${ }^{63}$ Ministeriet havde altså udpeget en kendt anti-nazist til ny rektor $\mathrm{i}$ Aabenraa. Det tyske mindretal var derfor stærkt utilfreds og lod da også hurtigt høre fra sig. Det skete i Flensburger Nachrichten få dage efter rektorindsættelsen, der fandt sted på det nye skoleårs første dag den 14. august 1941. I en notits den 18. august 1941 beklagede redaktionen sig over, at Buchreitz havde ladet sig interviewe til forskellige blade og fremsat udtalelser med brod mod det nationalsocialistiske Tyskland. Dermed beviste Buchreitz, at han ikke havde forandret sig siden sin tid som lærer ved det tyske gymnasium. Buchreitz havde imidlertid kun ladet sig interviewe til Hejmdal, og det må derfor være 
indholdet i dette interview, som tyskerne var utilfredse med. ${ }^{64}$ I Hejmdal den 13. august 1941 udtalte Buchreitz bl.a., at han i årene i Aabenraa 1930-1933 havde lært at sætte umådelig stor pris på den sønderjyske befolkning, som var lidt mere frigjort over for mangt og meget end andre steder, for "den, der før har redet en storm af, ved, at det også kan lade sig gøre en anden gang «. Buchreitz fastslog desuden, at »den vigtigste gave, mennesket har fået, er retten til personlig udvikling. Der findes ingen større ret for mennesket end retten til selv at forme sin livsanskuelse."

Buchreitz' udnævnelse blev kommenteret i augustnummeret af Junge Front, medlemsblad for de tyske nationalsocialistiske ungdomsorganisationer nord for grænsen, og desuden i Hamburger Fremdenblatt den 30. august $1941 .{ }^{65}$ Men herefter faldt der ro over sagen. Undervisningsministeriet selv fastslog, at der intet var at bebrejde Georg Buchreitz med hensyn til hans udtalelser i Hejmdal. ${ }^{66}$

\section{Gymnasieskolernes tysk-fjendtlige agitation}

Et års tid efter besættelsen øgedes spændingen mellem danskere og tyskere, og den tyske gesandt i København, Cecil von Renthe-Fink, som havde det overordnede ansvar for den tyske besættelsespolitik, bad i slutningen af maj 1941 Udenrigsministeriets direktør, O.C. Mohr, om et møde. Renthe-Fink ønskede navnlig at diskutere den »tysk-fjendtlige agitation « ved de danske gymnasieskoler. Gesandten henviste til, at statsminister Th. Stauning tidligere havde lovet igennem rektorerne at give gymnasieelever og -lærere ordre til straks at stoppe deres tyskfjendtlige virksomhed. Han ville gerne høre, om der var tilgået skolernes rektorer en sådan ordre, og hvis det var tilfældet, ville han foreslå, at den blev fulgt op af rejser af undervisningsinspektøren til de enkelte gymnasieskoler. O.C. Mohr kunne berolige Renthe-Fink med, at undervisningsministeren den 12. maj 1941 havde afholdt et møde med gymnasieskolernes rektorer, og at han her kraftigt havde understreget vigtigheden af, at såvel skolernes elever som deres lærere afholdt sig fra enhver form for tyskfjendtlig agitation. Undervisningsministerens synspunkter havde fundet tilslutning i Udenrigsministeriet. Både Udenrigsministeriet og Undervisningsministeriet var positivt indstillet over for tanken om at lade undervisningsinspektøren rejse rundt til de enkelte gymnasieskoler og fortsætte påvirkningen, og man var enige om, at han passende kunne starte 
i Sønderborg hos Rektor West! ${ }^{67}$ Mødet gav startskuddet til en lind strøm af cirkulærer, anordninger, bekendtgørelser og skrivelser fra Undervisningsministeriet til gymnasieskolernes rektorer, hvoraf der her skal gives et par prøver. ${ }^{68}$

I juni 1941 bad ministeriet rektorerne om indtrængende at pålægge eleverne at afholde sig fra demonstrationer af enhver art, og ministeriet gjorde opmærksom på, at "Demonstrationer i ord og gerning, som er egnede til at skade forholdet til de udenlandske styrker, der efter overenskomst med den danske regering befinder sig her i landet, straffes med bøde, hæfte eller fængsel $\mathrm{i}$ indtil to år. «" ${ }^{69}$ I februar 1942 meddelte ministeriet, at der fra nationalsocialistisk side var klaget over, at deres børn i skolen blev generet af kammeraterne med vold, tilråb og hånlig optræden. Ministeriet mindede rektorerne om, at en sådan opførsel øjeblikkelig skulle påtales og straffes efter forseelsens art samt indberetning herom ske til ministeriet. ${ }^{70}$ Sidst på året 1942 blev der fra tysk side klaget over, at elevblade på visse gymnasieskoler bragte artikler, som hånede besættelsesmagten. Ministeriet udsendte derfor straks et cirkulære, som pålagde rektorerne at føre nøje tilsyn med elevbladene. Ministeriet påpegede, at skolebladene ikke under nogen omstændigheder måtte beskæftige sig med indenrigseller udenrigspolitiske spørgsmål. ${ }^{71}$

I vinteren 1942/43 tilspidsedes situationen yderligere, og $\mathrm{i}$ januar 1943 var ministeriet endnu en gang nødt til at minde om forbudet mod demonstrationer mod besættelsesmagten og gjorde opmærksom på, at "også emblemer kan være af en sådan art, at der allerede i anvendelsen af dem ligger en forbudt demonstration. " $^{72}$ Bag denne skrivelse lå en stor irritation hos tyskerne over den om sig gribende brug af emblemer med påskrifter som f.eks. "Trods Alt«, emblemer i Royal Air Force-farver, emblemer med allieredes nationalflag o.a. ${ }^{73}$

Mange af disse ministerielle skrivelser irriterede rektorerne forfærdeligt, og de følte, at de blev til grin, hvis de hele tiden viderebragte forbud, hvis overholdelse de overhovedet ingen mulighed havde for at kontrollere. Aabenraa Statsskoles rektor, Georg Buchreitz, fortalte efter besættelsen, hvorledes det tit havde været svært for ham at skulle give ministeriets ordrer videre til eleverne, når han i hjertet var uenig med ministeriet $i$ dets politik, eller når han var nødt til at handle på en måde, som var hans overbevisning imod. Han fandt dog efterhånden en form, som både tilgodeså hans samvittighed og hans overbevisning. Han viderebragte derefter de ministerielle ordrer så- 
ledes, når han ved skolens morgensang skulle orientere om dem: „Det er fra højere sted blevet mig pålagt at pålægge jer, at ... «" Eleverne forstod godt, hvad den formulering betød, og Georg Buchreitz indrømmede da også, at det nok var en form for sabotage, men vel tilgivelig. Trods alt!

\section{Lektor Theodor Adler Lund}

På Sønderborg Statsskole var der nationale problemer, både blandt elever og lærere. I en indberetning fra politimesteren i Sønderborg til Statsadvokaten for særlige Anliggender i februar 1941 blev disse problemer konkretiseret: Der havde fundet slåskampe sted mellem danske og tyske elever og visse lærere optrådte uheldigt. Politimesteren henledte her i særlig grad opmærksomheden på en af statsskolens lærere, lektor Adler Lund, som politimesteren beskyldte for - især indenfor den af Adler Lund stiftede forening Det frie Danmark - at samle unge mennesker af begge køn, herunder gymnasieelever, om en særdeles yderliggående tyskfjendtlig agitation, nærmest baseret på et historisk grundlag. ${ }^{75}$ Statsadvokaten i Sønderborg tog dog afstand fra nogle af de stærkeste udtryk i politimesterens indberetning og tog endog afsluttende Adler Lund i forsvar: "Jeg tror ikke, der hernede, hvor man kender ham, tillægges hans udtalelser mere værd, end de fortjener, og de må ses i lyset af, at han i høj grad forstår at vække de unges interesse for og forståelse af nationale værdier. ${ }^{76}$

Adler Lund var kommet til Sønderborg Statsskole som adjunkt ved Genforeningen i 1920 og blev i 1929 udnævnt til lektor. Han var en ildsjæl, men også et uroligt gemyt, og i januar 1923 udtalte Sønderborg Statsskoles rektor, J.M. Hertz, i en skrivelse til ministeriet, at Adler Lund savnede ro og ligevægt i sindet, hvilket gik ud over kvaliteten af hans undervisning. ${ }^{77}$

Politimesterens rapport fra februar 1941 fik til følge, at undervisningsinspektøren for gymnasieskolerne anmodede Sønderborg Statsskoles rektor, A.J. West, om en erklæring om Adler Lund og hans virksomhed. Heri anførte rektoren, at der havde været afholdt et møde med Adler Lund, politimesteren og ham selv, og Adler Lund havde lovet for fremtiden at drage omsorg for, at intet provokerende ville finde sted. Han havde desuden forsikret, at han fremover ville optræde på en måde, så man ikke behøvede at beskæftige sig med ham. Rektor West kunne ikke optræde som garant for lektorens udad- 
vendte, nationale virksomhed, men omtalte i øvrigt Adler Lund positivt. ${ }^{78}$.

Men den tyske gesandt, Renthe-Fink, ønskede Adler Lund fjernet fra Sønderjylland. Han havde flere gange klaget over Adler Lund, idet han henviste til fortroligt materiale om ham. Sidst i maj 1941 blev Udenrigsministeriets direktør, O.C. Mohr, og chefen for Undervisningsministeriets 2. departement, Fr. Graae, enige om at meddele gesandten, at man kun kunne skride til en forflyttelse af Adler Lund, såfremt gesandten rent faktisk fremkom med noget af det materiale, som han hidtil havde omtalt som fortroligt. ${ }^{79}$ Få dage efter sendte Renthe-Fink til Udenrigsministeriet en klage over en række tyskfjendtlige ytringer, som Adler Lund ifølge en tysksindet elev skulle have fremsat i sin historieundervisning. Renthe-Fink anførte, at Adler Lund i en historietime i 1.g den 27. februar 1941, uden at det havde nogen forbindelse til det stof, der skulle gennemgås, fremkom med nogle bemærkninger om luftværnsforanstaltningerne i Sønderborg. Han skulle angiveligt have sagt, at byens luftværnsforanstaltninger ikke tjente noget formål, idet byen ikke ville blive bombet, så længe der var danske soldater i Sønderborg, og i øvrigt holdt England et vågent øje med alt, hvad der skete i Danmark. Adler Lund sagde senere i samme time, at alle danske så hen til den dag, hvor Elben atter blev Danmarks grænse mod syd. Renthe-Fink anforte videre, at Adler Lund i nogle af sine klasser med stort engagement havde fortalt følgende vittighed:

En "mellemeuropæisk statsmand" opsegte en klog kone og bad hende fortælle, hvordan Europas fremtid ville se ud. Konen anbefalede ham at gå op i bjergene og råbe sine spørgsmål ud, så ville svarene komme til ham som ekko. Statsmanden fulgte den kloge kones råd og råbte:

Wer beherrscht bald die grosse Welt?

Roosevelt, Roosevelt!

Wer wollte immer nur den Frieden?

Eden, Eden!

Wann liegt England auf dem Knie?

Nie, nie!

Welche ist die beste Nation?

Zion, Zion! $!^{80}$ 
I Undervisningsministeriet ville man have sagen nærmere undersøgt, og man accepterede et ønske fra tysk side om midlertidig bortvisning af læreren. Den sidste dag i sommerferien fik Adler Lund derfor af skolens nye rektor, A. Egeberg Jensen, at vide, at ministeriet med øjeblikkelig virkning havde suspenderet ham fra hans stilling, mens en undersøgelse af sagen stod på. I en indberetning til ministeriet indrømmede Adler Lund, at han havde fremsat en enkelt af de påståede ytringer, men hævdede, at de øvrige enten var forkerte eller fordrejede. Trods massiv støtte til Adler Lund fra forskellige kredse i Sønderborg besluttede ministeriet alligevel at forflytte ham til en lektorstilling ved Roskilde Katedralskole pr. 1. oktober $1941 .{ }^{81}$

Men Adler Lund kunne ikke tie! I Roskilde fortsatte han sin agitation, og i begyndelsen af oktober 1942 gjorde Justitsministeriet Udenrigsministeriet opmærksom på, at Adler Lund i De danske Gymnastikforeningers blad Ungdom og Idræt i nr. 37 og 39 fra henholdsvis 11. og 25. september 1942 havde skrevet artikler af tyskfjendtligt indhold. Efter at have læst de pågældende artikler anmodede Udenrigsministeriet Justitsministeriet om at rejse tiltale mod Adler Lund for overtrædelse af Lov nr. 388 af 22. juli 1940 §1, hvori det hedder: »Den, der ved trykt skrift eller på anden måde offentlig giver meddelelser, der er egnede til at skade landets interesser i forhold til udlandet straffes med fængsel indtil 1 år eller under formildende omstændigheder med hæfte eller bøde. « Desuden blev det besluttet, at eventuelle restoplag af ovennæunte numre af bladet blev beslaglagt. ${ }^{82}$

Den første af de to artikler, "National uklarhed - og klarhed!", virker læst $\mathrm{i}$ begyndelsen af det 21. århundrede forholdsvis harmløs og er i øvrigt særdeles velformuleret og vældig godt skrevet. Artiklen kan stort set reduceres til et enkelt spørgsmål: De danske nazister har lov til at agitere for tilslutning til Tyskland i et germansk fællesskab, det straffes ikke! Men hvis andre danskere agiterer for tilslutning til England, skader det vores forhold til udlandet, og de pågældende bliver straffet. Er det eneste udland, der findes, Tyskland?

Den anden artikel "Øjeblikkets storhed" virker derimod noget eksalteret og beskæftiger sig især med danskernes manglende racefællesskab med tyskerne, $i$ hvert fald set $i$ et historisk perspektiv. Desuden omtales tyskernes evindelige trang til ekspansion, $i$ dette tilfælde ønsket om at føre Danmark ind $\mathrm{i}$ et Storgermanien under Tysklands ledelse.

I begyndelsen af oktober 1942 besluttede Undervisningsministeriet, 
at Adler Lund endnu engang skulle suspenderes fra sin stilling, mens anklagerne mod ham blev undersøgt, og den 28. december 1942 blev der afsagt dom i sagen: Adler Lund blev straffet med hæfte i fire måneder. Sagen blev ikke anket. ${ }^{83}$ Så vel under de to suspensioner som under afsoningen arbejdede Adler Lund på en beretning om de lange udviklingslinier i Danmarks historie. Det blev til bogen Folkets Danmark. Et politisk tilbageblik fra systemskiftet til $1940 \mathrm{og}$ en udviklingslinie ind $i$ fremtiden. Bogen er på 86 sider og blev udgivet $i$ Toftlund $1945 . .^{84}$

Under Adler Lunds afsoning blev der i nazistiske kredse arbejdet ihærdigt på at få ham afskediget fra sin lektorstilling, når afsoningen var afsluttet. De danske nazisters blad National-Socialisten bragte den 21. januar 1943 en notits om Adler Lund. Indlægget sluttede således: "... Må vi spørge: Når hetzeren og provokatøren lektor Adler Lund har udstået straffen på de fire måneders hæfte, hvad så? Kan manden så fortsat som kongelig dansk pensionsberettiget embedsmand gå tilbage til sin gerning, bærende alle kort på hånden til at fortsætte hetzen blandt den skolesøgende ungdom, han kommer i berøring med? I så fald er vi ude i den rene karikatur, slet og ret! «

I Undervisningsministeriet prøvede embedsmændene at nå til enighed om, hvad der skulle ske med Adler Lund, når han blev løsladt. Der var stort set enighed om, at en afskedigelse på det foreliggende grundlag skulle undgås, idet det ude omkring ville blive betragtet som unødigt vidtgående og i øvrigt skabe bitterhed $\mathrm{i}$ vide kredse. Imod afskedigelse talte også, at den direkte anledning til forflyttelsen fra Sønderborg havde været de udtalelser, der var faldet $\mathrm{i}$ Adler Lunds historieundervisning, og at Roskilde Katedralskoles rektor intet som helst havde haft at udsætte på hans undervisning. Der havde heller ingen klager været over Adler Lunds undervisning, hverken fra elever eller forældre, kun sympatitilkendegivelser, og desuden havde han med frihedsstraffen bødet for sin forseelse med artiklerne. Derimod blev endnu en forflyttelse diskuteret, men departementets øverste chef, Fr. Graae, mente, det ville være uklogt at anvende dette disciplinærmiddel mere end én gang. Embedsmændene var dog enige om, at Adler Lund først måtte genoptage sin undervisning ved Roskilde Katedralskole efter sommerferien 1943, og der var ligeledes fuld enighed om, at han skulle have en alvorlig skriftlig misbilligelse med en bemærkning om, at spørgsmålet om en afskedigelse øjeblikkelig ville blive taget op til overvejelse, såfremt hans ad- 
færd fremover skulle give anledning til berettigede klager. Og sådan blev det. Den skriftlige advarsel blev sendt til Adler Lund den 13. maj 1943 og var underskrevet af undervisningsministeren. ${ }^{85}$

Adler Lund modtog $\mathrm{i}$ anledning af sin løsladelse fra fængslet en velkomstadresse afsendt af tidligere elever på Sønderborg Statsskole. Adressen havde følgende ordlyd: "Kære Adler Lund! Velkommen til Dem, Deres frue og lille pige - tilbage til friheden. Vi har været med Dem i vore tanker i den tid, da Deres sag stod på, og mens De som en gemen forbryder blev sat bag lås og lukke for at have udtrykt de tanker, som vi danske alle billiger. Vi håber på et snarligt gensyn i Sønderborg. Et velkommen tilbage til friheden. ${ }^{86}$ Sønderborgs politimester undersøgte sagen. Adressens tekst var angiveligt formuleret af Jens Helge Refslund, en tidligere elev i en af de gymnasieklasser, hvis elever netop var blevet studenter i juni 1943. Adler Lund havde i sin tid været historielærer for klassen, og der havde altid bestået et særdeles venskabeligt forhold så vel i som uden for skolen mellem Adler Lund og eleverne i den klasse. Efter Adler Lunds forflyttelse til Roskilde Katedralskole bevarede klassen forbindelsen med ham. En tysksindet elev havde imidlertid læst adressen og robet indholdet til politiet.

Det var ikke muligt at få fat på Helge Refslund, da han var forsvundet og $\mathrm{i}$ øvigt efterlyst som sigtet for sabotage mod fabrikken Skandia i Randers! Politimesteren i Roskilde blev bedt om at sende en politibetjent ud til Adler Lund og afkræve ham navne og adresser på de personer, der havde underskrevet velkomstadressen. Adler Lund forklarede betjenten, at han ganske rigtigt havde modtaget en skrivelse med "Velkommen tilbage", men om den var af samme ordlyd som den tekst, betjenten forelagde Adler Lund, huskede han ikke, idet han øjeblikkeligt havde tilintetgjort brevet. Han kunne således heller ikke huske navnene på underskriverne og ej heller deres adresser. ${ }^{87}$ Nogle af Refslunds tidligere klassekammerater blev dog afhørt og nogle af disse indrømmede at have skrevet under på adressen. Sagen blev afsluttet med en advarsel til de pågældende. ${ }^{88}$ Adler Lund genindtrådte i sit embede på Roskilde Katedralskole pr. 1. august 1943. Han døde den 1. februar 1947, få dage efter en operation. Han blev 64 år.

En kort sammenligning mellem Rosent-sagen og Adler Lund-sagen giver et tydeligt fingerpeg om ministeriets politik: Når lektor Viggo Rosent, Aabenraa Statsskole, to gange kunne komme godt af sted med at sige nej til ministeriets krav om forflyttelse til en skole langt væk fra grænselandet, skyldtes det, at ministeriet ikke anså Rosents 
bemærkning om "gadedrenge" en aften i slutningen af september 1938 som andet end en fortalelse fremsagt i ubetænksomhed. Ministeriets primære formål med forflyttelsen har været at beskytte Rosent mod de mange chikanerier og overgreb, som det tyske mindretal og de danske nazister udsatte ham for. Anderledes med lektor Adler Lund, Sønderborg Statsskole. Havde han sagt nej til at blive forflyttet i oktober 1941, ville ministeriet uden tvivl have afskediget ham. Adler Lund virkede nemlig med sin anti-tyske agitation ophidsende på det tyske mindretal i Sønderjylland.

Det var nu ikke den egentlige årsag til forflyttelsen. Grunden var, at Adler Lund i sin historieundervisning var fremkommet med tyskfjendtlige bemærkninger. Og derfor slog ministeriet til: Departementschef Fr. Graae og Udenrigsministeriets direktør, O.C. Mohr, opfordrede lige frem Renthe-Fink til skriftligt at fremkomme med nogle af de klager over Adler Lund, som gesandten hidtil blot havde nævnt fortroligt, så man i Undervisningsministeriet havde noget konkret at slå ned på. ${ }^{89}$ Her vidste man nemlig, at hvis ikke embedsmændene selv greb ind og stoppede Adler Lund, så kunne man risikere, at tyskerne benyttede sagen som påskud til at gribe ind $\mathrm{i}$ den danske skoles frihed. Og det var lige netop, hvad ministeriet for alt i verden ville undgå.

\section{Blev rektor West tvangsforflyttet?}

Centraladministrationen $\mathrm{i}$ København så med stor alvor på de nationale problemer i Sonderborg, og Undervisningsministeriet var opmærksom på, at en del af disse problemer relaterede til Statsskolen. At der var nationale problemer både blandt statsskolens elever og lærere, var naturligvis alvorligt nok. Men Undervisningsministeriet fandt endvidere den måde, hvorpå skolens rektor, Axel J. West, af og til forte sig frem, meget bekymrende: West optrådte tit meget egenrådigt og var alt for åbenmundet. Desuden var man utilfreds med, at han engang imellem ligefrem gik $\mathbf{i}$ rette med sine foresatte $\mathbf{i}$ København. ${ }^{90}$

Den 5. maj 1941 meddelte Undervisningsministeriet, at rektor A.J. West, var blevet udnævnt til rektor for Sorø Akademi pr. 1. august. Det kunne ligne en tvangsforflyttelse, for A.J. West var sønderjyde af fødsel og havde gennem mere end 20 år gjort et stort arbejde for den sønderjyske sag, som hans hjerte brændte for. Det skulle syntes umuligt, at han frivilligt kunne finde på at tage til Sjælland. Men West havde faktisk 


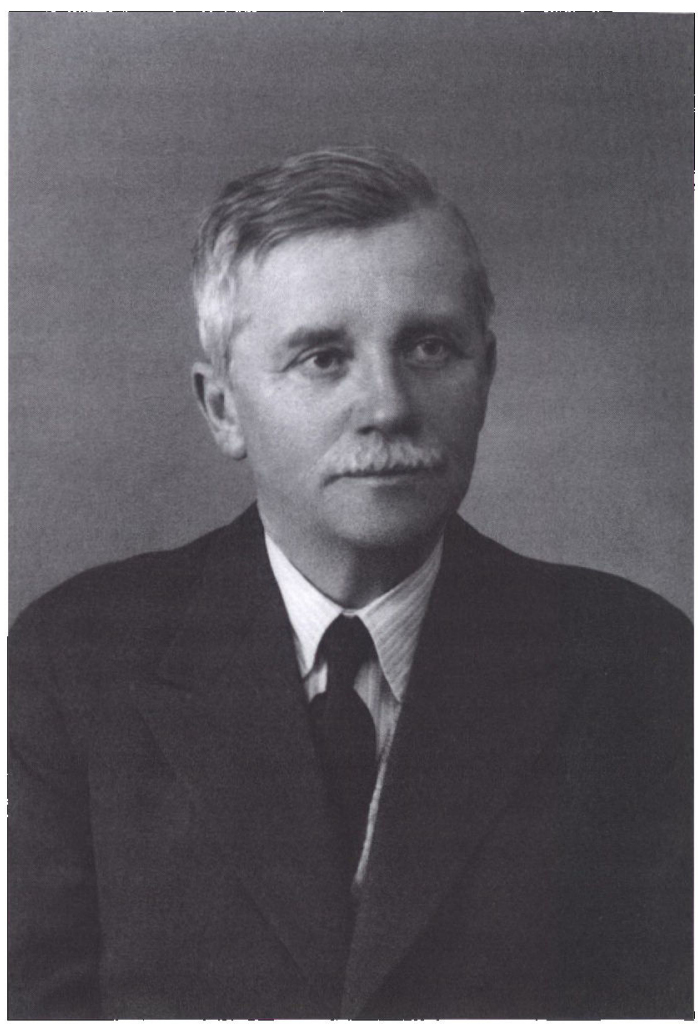

Axel Jürgensen West (1880-1943) blev i 1920 rektor ved Tonder Statsskole og i 1930 ved Sonderborg Statsskole, inden han afsluttede sin gerning ved Sorø Akademi, hoor han også tidligere havde undervist. A.J. West var en kompromisles anti-nazist, der var meget upopular hos det tyske mindretal. Det vakte derfor lettelse $i$ Undervisningsministeriet, da han sogte og fik stillingen som rektor på Soro Akademi i 1943. Foto: Senderborg Statsskole.

selv søgt om rektoratet i Sorø, og det havde han ualmindeligt gode grunde til: Han havde selv været elev på Sorø Akademi fra 1892-1898, og hans første embede som adjunkt 1914-1918 havde været på Sorø Akademi. Desuden skulle to af hans børn i efteråret 1941 påbegynde studier i København, og West og hans kone ville gerne være nær ved dem. West sluttede sin ansøgning således: „Det vil være både en ære og en glæde for mig at afslutte min skolegerning på det sted, hvor jeg som 12-årig indtrådte som elev $\mathrm{i}$ den højere skole, og hvor jeg første gang kom i statens tjeneste ${ }^{91}{ }^{91}$ Der er således ingen tvivl om, at West gerne ville til Sorø. Men det udelukker naturligvis ikke, at ministeriet var udmærket tilfreds med at skulle ansætte en ny leder på Sønderborg Statsskole. Og man vidste nøjagtigt, hvem man ville have! ${ }^{92}$ Nemlig Haderslev Katedralskoles rektor, A. Egeberg Jensen.

Da undervisningsinspektøren til ministeriet indstillede West til rektorembedet ved Sorø Akademi, skete det bl.a. med ordene:: "Trods 
iøjnefaldende fejl anser jeg ham for facile primus blandt ansøgerne... «93 A.J. West blev altså ikke tvangsforflyttet fra Sønderborg. Men han var ikke engang tiltrådt i Sorø endnu, før tyskerne forlangte ham tvangsforflyttet herfra! Sidst i maj 1941 henvendte den tyske gesandt Renthe-Fink sig i Udenrigsministeriet med en klage over rektor Wests »anti-tyske« agitation og forlangte, at han blev tvangsforflyttet fra sin nye stilling som rektor i Sorø. Undervisningsministeriet anførte snusfornuftigt, at man jo ikke kunne forflytte en mand fra en stilling, som han endnu ikke havde tiltrådt. $O g$ det syntes gesandten at acceptere. ${ }^{94}$

\section{Krav om revision af skolebøger}

Tyskerne gjorde ikke på noget tidspunkt forsøg på direkte at gribe ind i den danske skoles indre forhold ved at søge at nazificere undervisningens principper og indhold, således som det f.eks. var tilfældet i Norge. Selv om besættelsesmagten opfattede det som et stort problem, forsøgte den således aldrig at ændre på, at gymnasieskolernes hovedfag på den nysproglige linie var engelsk, og den forsøgte heller ikke at gribe ind i gymnasieskolernes administrative ledelse. ${ }^{95}$

En undtagelse var dog tyskernes reaktion over for skolebøgerne. I 1930 var der blevet nedsat et skolebogsudvalg med repræsentanter fra Undervisningsministeriet, Københavns Universitet og Folketinget med det formål at gennemgå skolernes dansk-, historie-, geografi- og religionsbøger og sikre sig, at de ikke var nationalistiske. Den generelle kritik af de danske historiebrger gik på, at de ofte med deres glorificerende krigsbeskrivelser og nationale selvforherligelse skabte grobund for nationale modsætninger i stedet for at bygge bro mellem nationerne. ${ }^{96}$ Betænkningen udkom i 1933, og i 1937 nedsatte private i god forståelse med Undervisningsministeriet et skolebogsudvalg, som ville undersøge de tyske historiebøger for at se, hvorledes disse beskrev forholdet til Danmark. I 1941 blev udvalget pga. klager fra tysk side over visse danske skolebøger bedt om at udvide deres undersøgelse til også at omfatte danske historiebøger samt det historiske indhold i danske geografibøger med særlig henblik på beskrivelsen af forholdet mellem Danmark og Tyskland. ${ }^{97}$ Tyskernes kritik gjaldt for gymnasieskolernes vedkommende især tre lærebøger, nemlig P. Læssøe Müller og Ingemann Ottosen: Engelske talere, 2. hefte, som bl.a. indeholdt Lloyd George's tale af 19. september 1914 om tyskernes forhold til Belgien, og Carl Gad: Moderne tyske noveller, hvis titel ty- 
skerne protesterede imod, fordi de ikke kunne tolerere, at en bog, der væsentligst indeholdt jødisk litteratur og emigrantlitteratur, blev betegnet som moderne tysk litteratur.

Den tredje lærebog, som tyskerne ankede over, var Ludvig Schmidt: Frankrigs, Tysklands og Englands historie siden 1860, 6. udgave fra 1938, som var revideret af rektor for Sønderborg Statsskole A.J. West, og som efter tyskernes mening indeholdt en række passager, som var uvenlige mod Tyskland. En sammenligning mellem bogens 6. udgave og den ligeledes af A.J. West reviderede 7. udgave fra 1942 viser, at West både lyttede til den generelle kritik af de danske historiebøger og til tyskernes kritik. ${ }^{98}$

Skolebogsudvalget afgav betænkning i september 1942, og resultatet af undersøgelserne kunne ifølge undervisningsinspektør Højberg Christensen kort sammenfattes således, at de danske lærebøger i de senere år var blevet noget nær uangribelige, medens de tyske skolebøger indeholdt højst angribelige ting! ${ }^{99}$

\section{"Først så ta'r vi Göring ...«}

I 1942 sporedes en markant stigning i antallet af demonstrationer rettet mod besættelsesmagten, ligesom der skete en kraftig forøgelse af registrerede sabotagehandlinger. Også i gymnasieskolerne mærkede man en stigende tendens til at vise mishag med tyskernes tilstedeværelse i landet, og besættelsesmagten blev efterhånden klar over, at de havde bitre fjender blandt gymnasieskolernes elever. ${ }^{100}$ I sammenligning med det antal episoder, som indtil 29. august 1943 blev indberettet til ministeriet fra gymnasieskolerne, er antallet af indberettede episoder fra folkeskolerne, mellem- og realskolerne, højskolerne, ungdomsskolerne og seminarierne ubetydeligt. ${ }^{101}$

I Sønderjylland holdt både det tyske mindretal og de danske nazister et vågent øje med de fire gymnasieskoler, og her kom rektorerne hyppigt på et større efterforskningsarbejde, når klager skulle undersøges, og en hurtig indberetning til ministeriet udarbejdes. Gang på gang mindede ministeriet rektorerne om deres pligt til at udarbejde en indberetning til ministeriet, når en sag relaterede til den øjeblikkelige politiske situation i landet. »Overalt, hvor det drejer sig om, at en fjendtlig stemning giver sig udslag $i$ aktiv handling, må denne påtales og straffes efter forseelsens art samt indberetning herom ske til ministeriet", hed det $\mathbf{i}$ en ministeriel cirkulærskrivelse til gymnasieskolernes rektorer 23 . fe- 
bruar 1942. Det ser ud til, at i hvert fald de sønderjyske rektorer normalt ordnede det sådan, at hvis en sag kunne holdes inden for skolens mure, så klarede rektorerne den som regel selv, men kunne en sag ikke lukkes øjeblikkeligt, og var der fare for, at den på et tidspunkt ville nå ud i den trykte presse, så blev den øjeblikkeligt indberettet til ministeriet. Der kunne også være tilfælde, hvor en klagende person eller myndighed som betingelse for at lukke en sag krævede, at den blev indberettet til ministeriet, og i de tilfælde blev der også, som det ses af Lili Marleensagen, indsendt en indberetning.

Lili Marleen-sagen begyndte således: Fredag den 23. januar 1942 henvendte skræddermester L. Nielsen sig om aftenen i Aabenraa Statsskoles rektorbolig og bad om en samtale med rektor Georg Buchreitz. Skræddermesteren, der var dansk nazist, fortalte, at han havde en son i skolens 2. mellem (svarede til nuværende 7. klasse - gymnasieskolerne optog på dette tidspunkt eleverne fra og med 6. klasse). Sonnen havde samme dag $i$ en sangtime med adjunkt Helge Gad været ude for en hændelse, som han betragtede som kriminel, og som han pga. sin stilling inden for DNSAP var nødt til at indberette til sin sysselleder. Forløbet havde været således: I begyndelsen af sangtimen havde nogle af drengene bedt om lov til at synge en sang på en i de dage meget kendt melodi, Lili Marleen. ${ }^{102}$

Læreren havde sagt nej, for den melodi brød han sig ikke om. Derefter havde to af drengene spurgt, om de så ikke måtte synge sangen for deres klassekammerater alene, hvilket læreren gav dem lov til. Derefter sang de to drenge melodien på denne tekst:

Forst så ta'r vi Gøring
i hans tykke ben,
dernæst ta'r vi Gobbels
og slår ihjel med sten,
Hitler han hænges i en strop
ved siden af von Ribbentrop.
Der hænger de til grin
de fire dumme svin!

Da sangen var sunget til ende, havde læreren sagt »Tak, det er godt! «, hvorefter man havde påbegyndt undervisningen. Sønnen havde skrevet teksten ned direkte efter afsyngelsen, og faderen påpegede, at det kriminelle lå i teksten, idet man tilsvinede en fremmed stats overho- 
ved. Rektor lovede straks at undersøge sagen, og faderen, som i øvrigt optrådte både venligt og høfligt, lovede ikke at foretage sig yderligere, før de havde talt sammen igen.

Rektor sendte øjeblikkelig bud efter Helge Gad, som stort set bekræftede forløbet. Han undskyldte sig dog med, at han ikke havde bidt mærke i teksten, idet de to syngende drenge havde stået et godt stykke fra ham. Læreren fremhævede yderligere, at han med bemærkningen "Tak, det er godt! « ikke havde ment, at det var godt, men nærmere, at nu var det altså nok. Rektor spurgte læreren, om han kendte teksten i forvejen, og denne måtte nødtvungent indrømme, at det gjorde han, idet han nogle dage før havde skrevet verset af efter en elev i 1.g.

Derefter sendte rektor Buchreitz bud efter skræddermesteren, som straks indfandt sig. Rektor fremstillede for ham sagen i adjunkt Gads version og i dennes nærvær. Faderen blev nu usikker og sagde, at han måtte tale med sin søn igen. Da skræddermesteren var gået, bebrejdede rektor Buchreitz adjunkt Gad, at han havde ladet det komme så vidt, og påpegede endnu stærkere det helt uforsvarlige $\mathrm{i}$ (hvad faderen ganske vist ikke vidste), at læreren få dage før havde afskrevet verset efter en elev i 1.g og således var bekendt med teksten i det øjeblik, da de to drenge begyndte at synge. Samtalen sluttede med, at rektor gav Helge Gad en tjenstlig irettesættelse samt gjorde opmærksom på, at han den følgende dag ydermere ville modtage en skriftlig advarsel fra ham. I skrivelsen udtrykte rektor sin misbilligelse af adjunktens adfærd, men gav samtidig udtryk for sin tillid til, at det dels drejede sig om et isoleret tilfælde, dels at det ikke ville gentage sig.

Rektor ville nu for enhver pris undgå, at episoden kom offentligt frem, og han tilkaldte derfor straks den følgende formiddag de to syngende drenge og bebrejdede dem deres opførsel, ligesom han ved skolens morgensang samme dag kraftigt fremhævede det ulovlige $i$, at tekster, som gjorde grin med navngivne tyskere eller med tyskere $i$ almindelighed, blev bragt med i skole, og rektor understregede de alvorlige konsekvenser, det kunne få for de elever, der blev taget $i$ at overtræde forbudet. Rektor kontaktede derefter skræddermesteren og orienterede ham om, hvad der var sket i sagen, siden de havde taget afsked med hinanden aftenen før, samt oplyste ham om, at der i begyndelsen af den følgende uge i overensstemmelse med faderens ønske ville blive sendt en indberetning om sagen til ministeriet. Faderen syntes tilfreds og lovede til gengæld, at han ikke ville foretage sig mere.

Samme dag blev skræddermesteren imidlertid ringet op af den lo- 


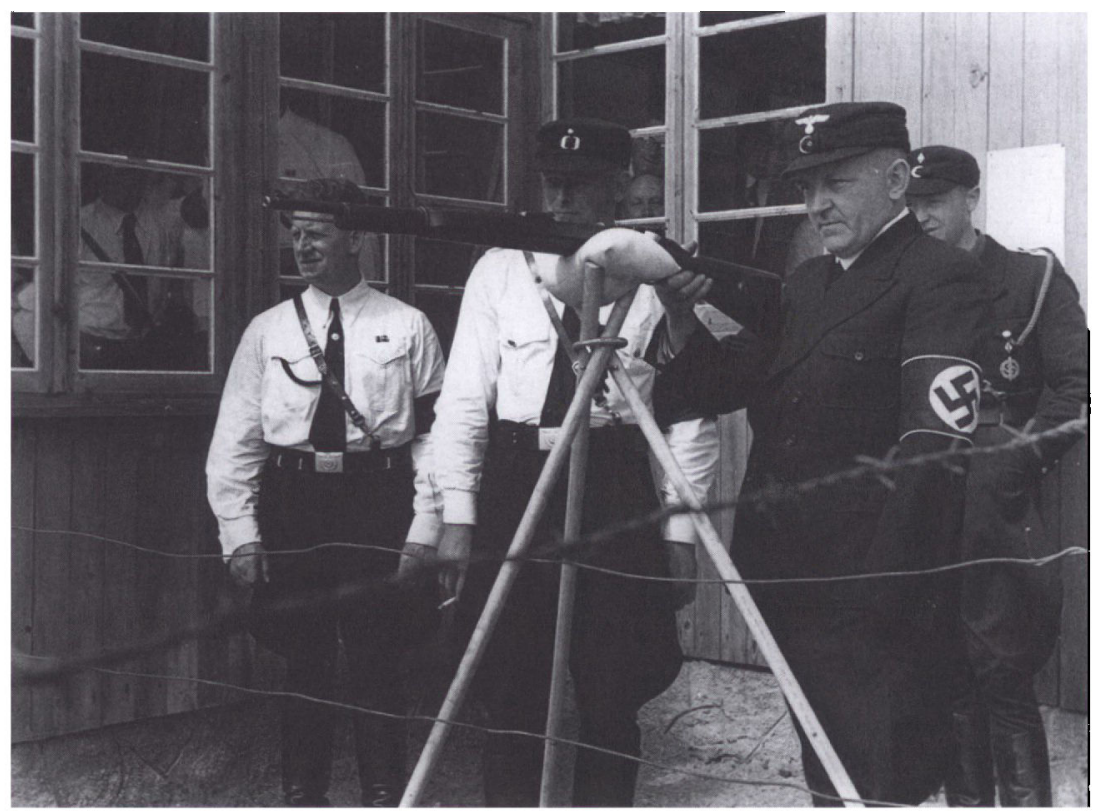

Peter Larsen (1892-1983) stammede oprindeligt fra et dansksindet hiem, men blev allerede $i$ sin tidlige ungdom tysksindet. Under Forste Verdenskrig avancerede han til Oberleutnant og sluttede krigen som hojt dekoreret - og krigsinvalid. Han blev tidligt nazist og medlem af NSDAP-N og fik ansvar for de uniformerede SK (Schleswigsche Kameradschaft), Zeitfreiwillig- og Selbstschutzkorps. Peter Larsen var desuden leder af Organisationsamt og plejede tatte forbindelser med besættelsesmagtens efterretningsorganer, til hwem han indberettede om tyskfjendtlige personer og organisationer $i$ grænselandet. Peter Larsen ses her ved indvielsen af en skydestand $i$ Tandslet den 19. juli 1942. Foto: Rudolf Gintm. Museum Sonderjylland. Institut for sønderjysk lokalhistorie.

kale leder af det tyske mindretals politiske arbejde, overløjtnant Larsen, Rødekro, som spurgte, om han kendte noget til en nærmere bestemt sag. Det viste sig at være den her refererede, som overløjtnanten fra anden side var blevet underrettet om. Skræddermesteren bekræftede, hvorefter han blev indkaldt til en samtale med overløjtnanten samme dag. Under samtalen følte faderen sig nødsaget til - på trods af aftalen med rektor - at referere forløbet $i$ enkeltheder. ${ }^{103}$

Det vides ikke, hvem der herefter gik videre med sagen. Men den nåede en af de følgende dage redaktøren af Nordschleswigsche Zeitung, som den 10. februar $1942 \mathrm{i}$ avisen skrev et harmdirrende indlæg, hvori han udtrykte sin bestyrtelse over, at dansk ungdom blev opdraget på en sådan måde, at den kunne få sig selv til at digte smædevers. Han 
beskyldte de sønderjyske skoler for at være arnestedet for den giftige tekst, som nu yderligere viste sig ikke kun at bestå af det her citerede vers, men af $\mathbf{i}$ alt fire. Artiklen sluttede med ligefrem at insinuere, at danske lærere i Sønderjylland prædikede had til Tyskland. Georg Buchreitz erklærede siden, at misforholdet mellem episoden på Aabenraa Statsskole og artiklens beskyldninger var »stort «. ${ }^{104}$

Udenrigsministeriet blev af sit pressebureau underrettet om artiklen i Nordschleswigsche Zeitung og anmodede om et eksemplar af den pågældende udgave samt en afskrift af sangens fire vers. Efterfølgende bad Udenrigsministeriet Undervisningsministeriet om at gøre artiklen til genstand for en undersøgelse. ${ }^{05}$ Men Undervisningsministeriet fandt Nordschleswigsche Zeitungs beskyldninger mod de danske lærere for at være ikke blot positivt danske i deres opdragergerning, men også anti-tyske, aldeles grundløse. Man mente heller ikke, at der var hold i beskyldningerne om, at de dansksprogede skoler bidrog til udbredelse af den omtalte smædesang, og man ønskede derfor sagen afsluttet så hurtigt som muligt. Man forhørte sig dog hos amtsskolekonsulenterne, som svarede, at man ikke i de skoler, som sorterede under dem, var bekendt med de omtalte vers. Undervisningsministeren meddelte derefter i september 1942 Udenrigsministeriet, at man ikke fandt anledning til at foretage sig yderligere. ${ }^{106}$

\section{Efter den 29. august 1943}

Den 29. august 1943 indtraf det brud med tyskerne, som mange danskere gennnem længere tid havde ønsket - og andre frygtet. Den tyske rigsbefuldmægtigede i Danmark, Werner Best, var nogle dage for blevet kaldt til Berlin og vendte 28. august tilbage med så vidtgående krav til den danske regering, at svaret måtte blive et "Nej!« Kravene var bl.a. øjeblikkelig indførelse af undtagelsestilstand samt dødsstraf for sabotage og angreb mod værnemagten. Med regeringens afvisning af de tyske krav ophørte den med at fungere, og Rigsdagen undlod at indkalde til møder. Samarbejdspolitikken var slut. Den øverstkommanderende for de tyske tropper i Danmark, general von Hanneken, meddelte, at han ikke ville tolerere, at ministeriernes embedsmænd forlod deres poster. Hvis nogle af de ministerielle embedsmænd nægtede ufortrødent at fortsætte deres arbejde, ville de strengeste bestemmelser blive bragt $\mathrm{i}$ anvendelse. Det blev således de enkelte ministeriers øverste chefer, departementscheferne, der måtte tage ansvaret for videre- 


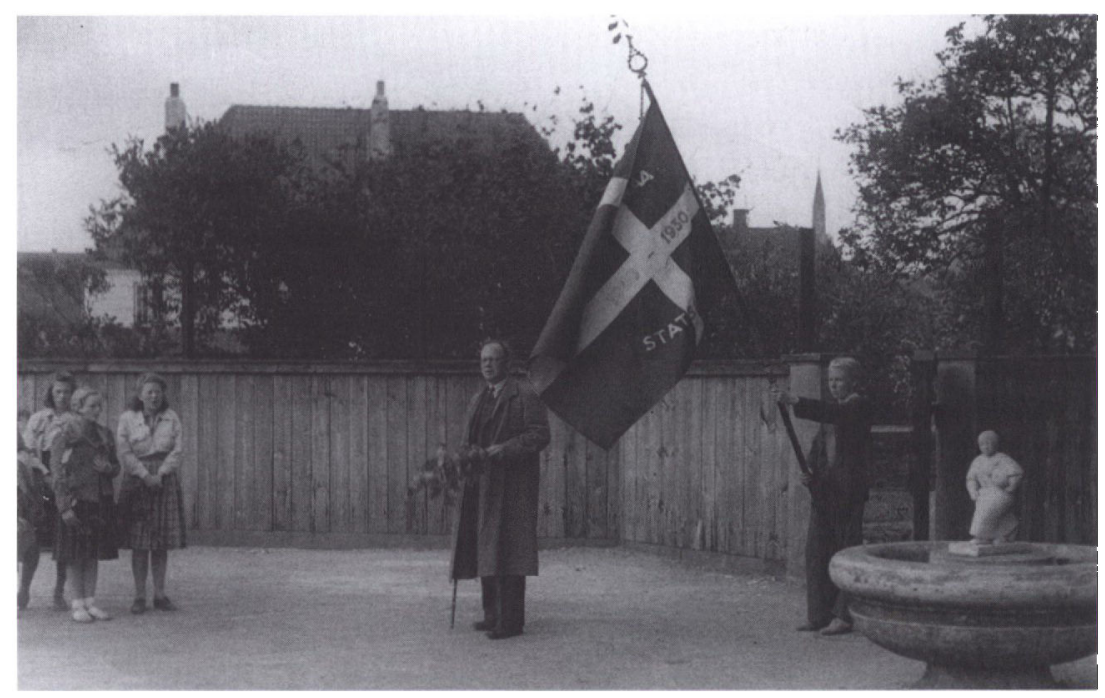

Georg Niels Thygesen Buchreitz (1905-1985) blev dansklærer ved Deutsche höhere Schule i Aabenraa i 1930, men forlod skolen og byen igen i 1933. I $1941 \mathrm{kom}$ han tilbage som rektor af Aabenraa Statsskole. Ved samarbejdspolitikkens sammenbrud den 29. august 1943 blev han arresteret af tyskerne og holdt som gidsel, men blev losladt igen den 10. september 1943. Da Georg Buchreitz kom tilbage til sin skole, blev han modtaget ved en ceremoni $i$ skolegården den 12. september 1943. Foto: Museum Sonderjylland. ISL - Lokalhistorie.

førelsen af statsadministrationen. ${ }^{107}$ For Undervisningsministeriets vedkommende blev det departementscheferne A. Barfod og Fr. Graae. Sidstnævnte havde fortsat størstedelen af sagerne vedrørende gymnasieskolerne som et af sine ansvarsområder.

Tyskerne strammede straks grebet om Danmark, og allerede kl. 4 om morgenen den 29. august 1943 blev der indført undtagelsestilstand. En del skolefolk blev arresteret, deriblandt de to sønderjyske rektorer Georg Buchreitz, Aabenraa Statsskole, og N.H. Jacobsen, Haderslev Katedralskole. ${ }^{108}$ De to rektorer led ikke overlast under det ufrivillige ophold, men især uvisheden var belastende. De vidste ikke, hvad grunden til arrestationen var, og de anede ikke, hvor længe de ville blive tilbageholdt. Den 8. september 1943 blev Georg Buchreitz flyttet fra Aabenraa Arresthus til Fredericia Kaserne, og her blev han under trange kår anbragt sammen med bl.a. sin kollega N.H. Jacobsen og den kendte sønderjyske forfatter og foredragsholder, seminarielærer Claus Eskildsen, Tønder Statsseminarium. Både N.H. Jacobsen og Georg Buchreitz blev løsladt den 10. september 1943. ${ }^{109}$ På opfor- 
dring skrev Georg Buchreitz få dage efter løsladelsen en redegørelse til Justitsministeriet om opholdet. ${ }^{110}$ Der blev ikke givet nogen forklaring på arrestationerne den 29 . august 1943, men et rygte ville vide, at det var mindretallets ungdomsorganisationer, der havde udpeget gidslerne. Det vides imidlertid ikke med sikkerhed. Men det var ganske tydeligt, at tyskerne havde gymnasieskolerne i kikkerten. ${ }^{111}$

Selv om der $\mathrm{i}$ den første periode af besættelsestiden, indtil 29. august 1943, kan opregnes en række konfliktsituationer, var der trods alt tale om et forholdsvis roligt forløb, hvor størstedelen af de fire sønderjyske gymnasieskolers elever og lærere bestræbte sig på at efterkomme regeringens påbud om at optræde roligt og værdigt over for besættelsesmagten. Efter 29. august 1943 ændrede gymnasieskolernes situation sig imidlertid markant, og vanskelighederne i det daglige arbejde blev i mange henseender øjeblikkelig mangedoblet. ${ }^{112}$

Men på ét punkt skete der dog - set med danskernes øjne - en ændring til det bedre. Situationen på krigsskuepladsen havde nemlig igennem nogen tid udviklet sig særdeles ugunstigt for tyskerne, og det påvirkede både det tyske mindretal og de danske nazister. Allerede i slutningen af 1942 beskrev politimesteren i Aabenraa ændringen blandt de tysksindede således: "Pessimismen med hensyn til krigens udfald synes at brede sig blandt det tyske mindretal, hvis tone er blevet betydelig mere sagtmodig. Skriftlige henvendelser fra mindretallet, som hidtil væsentligt har været affattet på tysk, er nu oftere affattede på dansk og underskrevet 'Ærbødigst' i stedet for 'Heil Hitler'. De danske nazister holder sig i ro. ${ }^{113} \mathrm{Og}$ politimesteren i Tønder skrev i august 1943, at stemningen hos det tyske mindretal var sunket yderligere, antagelig under påvirkning af den seneste tids begivenheder. ${ }^{114}$ De førhen så hyppige klager fra tyskorienterede hjem over chikane og drillerier ("Gehässigkeiten“) af deres børn i skolerne blev også færre, lige som man kunne notere en betydelig nedgang $i$ antallet af provokerende artikler i den nationalsocialistiske presse om dette emne. ${ }^{115}$ Men de forsvandt dog langtfra helt.

\section{Gestapos efterforskning på skolerne}

I første periode af besættelsestiden gik rektorernes opgave nærmest ud på at forhindre eleverne i udfordrende optræden over for de tysksindede og over for værnemagten. Efter 29. august 1943 udviklede situationen sig således, at rektorernes opgave nu snarere blev at beskytte ele- 
verne mod værnemagten og det tyske politi, Gestapo. For efterhånden som modstandsbevægelsen voksede, drog den også mange gymnasieelever med sig, og rektorerne kom nu gang på gang til at stå over for Gestapo, der indfandt sig på skolerne og krævede oplysninger om visse elever eller ligefrem forlangte at få dem udleveret. ${ }^{116}$

Rektorerne var i tvivl om, hvorledes de skulle forholde sig, når tysk politi pludselig dukkede op. Derfor gjorde de en af de første dage i november 1943 departementschef i Undervisningsministeriet Fr. Graae opmærksom på problemet og udbad sig direktiver. Han udarbejdede straks nogle retningslinier, som den 5 . november blev godkendt på et departementschefmøde. Udkastet blev derefter forelagt Justitsministeriet til gennemsyn, og med nogle få tilføjelser og omformuleringer blev det udsendt som fortroligt cirkulære til gymnasieskolernes rektorer et par dage senere. ${ }^{117}$ I cirkulæret blev rektorerne nøje instrueret $i$, hvad de skulle gøre, hvis en tysk politimyndighed henvendte sig på skolen. Hvis der blev anmodet om oplysninger om en navngiven elev, skulle de omgående kontakte elevens hjem og måtte efterfølgende kun give de oplysninger fra sig, som fremgik af skolens protokoller eller lignende officielt materiale. Såfremt en tysk politimyndighed bad om tilladelse til at foretage efterforskning eller lignende på selve skolen, skulle rektor ved forhandling forsøge at få det undgået. Hvis det ikke lykkedes, skulle rektor kontakte Undervisningsministeriet. Hvis det blev ham nægtet, skulle rektor tilkendegive, at efterforskningen skete uden skolens tilladelse. Rektorerne blev pålagt straks at informere Undervisningsministeriet om enhver henvendelse til skolen fra en tysk politimyndighed. Cirkulæret indeholdt tillige en anmodning om, at rektorerne over for skolens elever ville indskærpe overholdelsen af fem af de cirkulærer, der tidligere var blevet udsendt, og som ministeriet vedlagde. ${ }^{118}$

Cirkulæret skabte uro blandt landets rektorer, og 12 . november 1943 henvendte en deputation sig i Undervisningsministeriet med en skriftlig henvendelse, hvori man protesterede mod dele af cirkulæret. I henvendelsen fastslog rektorerne bl.a.: "... at det vil virke ødelæggende på et hvert tillidsforhold til såvel elever som forældre og lærere, dersom vi under nogen form skulle medvirke til at udlevere elever til tysk politi. “119 Departementschef Fr. Graae erklærede, at det var rektorerne selv, der havde bedt om direktiver, at cirkulæret var udarbejdet i samarbejde med Justitsministeriet, og at bestemmelsen om rektorernes medvirken til at udlevere elever til Gestapo var i 
overensstemmelse med, hvad der gjaldt for tilsvarende forhold $i$ andre grene af administrationen. Derefter udtalte departementschefen dog, at hvis han var rektor, så ville han på eget ansvar tage det standpunkt aldrig frivilligt at medvirke til udlevering af nogen under hans forsorg værende elev. Men han fastslog videre, at han ikke som ministeriel embedsmand $i$ en vejledning fra ministeriet kunne give rektorerne besked på at optræde på en måde, som faktisk kunne ende med at gå ud over vedkommende rektor personligt. Deputationen erklærede sig herefter tilfreds med ministeriets indstilling. ${ }^{120}$

Også et stigende antal lærere deltog i modstandskampen, og Gestapo henvendte sig af og til på skolerne for at få fat på lærere. Bestyrelsen for statsskolelærernes faglige organisation, Gymnasieskolernes Lærerforening (GL), henvendte sig derfor den 2. december 1943 til Udenrigsministeriet med en bøn om at rette henvendelse til de tyske myndigheder og fremhæue det ønskelige $i$, at de sager, der blev behandlet af tyske myndigheder, og hvor lærere ved danske skoler var indblandet, blev fremmet mest muligt, således at der blev taget størst muligt hensyn til skolernes arbejde og opretholdelsen af ro og orden i disse. Det blev i skrivelsen kraftigt påpeget, at skolernes lærerpersonale i forvejen var begrænset, og at det var et alvorligt tab, så snart en lærer blev fjernet fra arbejdet. ${ }^{121}$

I april 1944 modtog Undervisningsministeriet en lignende henvendelse fra en sammenslutning af lærerorganisationer. Henvendelsen blev videresendt til Udenrigsministeriet, som svarede, at man ved passende lejlighed ville gøre den tyske rigsbefuldmægtigede, Werner Best, opmærksom på onskeligheden af at undgå arrestationer på skolerne. Best forsikrede $i$ et svar i oktober 1944 Udenrigsministeriet om, at det tyske sikkerhedspoliti kun ville foretage arrestationer på skolerne, når der ikke forelå andre muligheder. Henvendelserne fra lærerorganisationerne var i det daglige skolearbejde $i$ vanskelige situationer en meget stor støtte for skolernes ledere, som ved at stå sammen og følge en fast kurs utvivlsomt var medvirkende til, at besættelsesmagten ikke på noget tidspunkt som i Norge påtænkte kollektive anholdelser af lærere og elever. Skolernes område blev stort set bevaret som fredlyst område. ${ }^{122}$

\section{Modstandsarbejde i de sønderjyske gymnasieskoler}

Elever og lærere på de fire sønderjyske gymnasieskoler var tidligt på færde med protester mod tyskerne. Det tyske mindretal og de danske 
nazister i Sønderjylland begyndte at slå på stortromme $\mathrm{i}$ begyndelsen af 1930 'erne, og kort tid efter Hitlers udnævnelse til tysk rigskansler i 1933 afstak Det unge Grænseværn retningslinierne for det nødvendige ungdoms- og oplysningsarbejde og fastslog, at det ikke kun var Kongeå-grænsen, nazisterne rakte hænderne ud efter, men hele Norden. Allerede da fandt adskillige sønderjyske elever og lærere i deres fritid sammen først i studiekredse og i forskelligt agitationsarbejde og senere under besættelsen i modstandsbevægelsen. Det er efter tyskernes kapitulation i maj 1945 blevet sagt, at var de sønderjyske gymnasier end tidligt ude, så er der intet, der af den grund tyder på, at de kom til at lide mere under besættelsen end mange andre gymnasieskoler i Danmark, måske oven i købet tværtimod. ${ }^{123}$ Noget kunne tyde på, at den påstand er rigtig. I hvert fald leder man i Undervisningsministeriets journalregistre over indgåede skrivelser 1943-1945 forgæves efter indberetninger fra de sønderjyske rektorer om efterforskning og anholdelser på deres skole. Der er faktisk ingen! Heller ikke i de principielle sager over anholdelse af elever på danske gymnasieskoler eller i navnefortegnelsen over enkeltsager, er der opført et eneste navn, som relaterer til de sønderjyske gymnasier. ${ }^{124}$

Når der ikke fra sønderjyske rektorer er tilgået ministeriet indberetninger om henvendelser fra tyske politimyndigheder, kunne det tyde på, at rektorerne i Sønderjylland har tolket ministeriets cirkulære af 8 . november 1943 således, at hvis en tysk politimyndighed mødte op på skolen og forlod den igen uden at have foretaget afhøringer eller anholdelser, så var en ministeriel indberetning ikke nødvendig, for vi kan nemlig bl.a. i skolernes års- og jubilæumsskrifter læse om Gestapobesøg på skolerne. En af de mere pudsige episoder foregik på Haderslev Katedralskole: En elev, Poul Futtrup, der i et stykke tid havde deltaget i forskelligt illegalt arbejde, blev i et frikvarter stoppet af Gestapo på en af skolens gange. De tyske soldater spurgte ham, om han kendte en dreng, der hed Futtrup. Han bevarede roen og svarede, at det gjorde han, og at drengen lige var styrtet ud af den dør dernede, da han så de tyske Gestapo-mænd, hvorefter disse spurtede af sted for at få fat på ham. Futtrup løb lige så hurtigt den modsatte vej og undslap!125

Der blev altså tilsyneladende ikke foretaget anholdelser på de fire gymnasieskoler. Men det betyder naturligvis ikke, at ingen af skolernes lærere eller elever blev anholdt af tyskerne. Alle fire skoler kan berette både om lærere og elever, der fik deres hjem gennemsøgt af Gestapo, om anholdelser i hjemmene og om pågribelse og arrestation 
under udførelse af sabotage eller anden illegal virksomhed, og på alle fire skoler måtte nogle lade livet $i$ kampen for friheden. Desuden måtte en del lærere og elever $\mathrm{i}$ de sidste måneder af besættelsen flygte, fordi de var eftersøgt af Gestapo. Også Haderslev Katedralskoles rektor N.H. Jacobsen og frue, som i en periode havde huset en tidligere elev, der af Gestapo var eftersøgt for sabotage, måtte gå under jorden. Den 13. april 1945 blev rektorparret klar over, at tyskerne havde fået færten af, hvem der havde holdt den pågældende sabotør skjult, og de så derfor ingen anden udvej end at flygte. ${ }^{126}$

Når elever og lærere blev arresteret af Gestapo, ydede Undervisningsministeriet hjælp i det omfang, det var muligt. Også Udenrigsministeriet blev involveret, idet man gennem hele besættelsestiden uden undtagelser fulgte den praksis, at henvendelser fra Undervisningsministeriet til tyske myndigheder skulle gå gennem Udenrigsministeriet. En gennemgang af sager om anholdelse af lærere og elever 1943-1945 viser, at når lærere blev arresteret, tog centraladministrationen sig af sagen. Når elever blev anholdt, var det den pågældende skoles rektor, som tog sig af sagen, dog i tæt samarbejde med Undervisningsministeriet, der altid skulle spørges, før endelige beslutninger blev truffet. Der skal her kort berettes om to sager: En sag om arrestation af lektor Rosenkjær i Tønder og en optrævling og anholdelse af medlemmerne af en såkaldt drenge-»sammensværgelse i Sønderborg.

\section{Lektor Aage Rosenkjær}

Lektor Aage Rosenkjær, Tønder Statsskole, blev arresteret i sit hjem af det tyske sikkerhedspoliti den 11. december 1943 og indsat i Kolding arrest. Undervisningsministeriet blev af skolens rektor, Jakob Randrup, underrettet om anholdelsen, og ministeriet ringede straks til statsadvokaten, som lovede at gøre, hvad han kunne for at få Rosenkjær løsladt øjeblikkeligt. Gymnasieskolernes Lærerforenings advokat, Leif Gamborg, henvendte sig personligt til de tyske myndigheder i hovedkvarteret på Dagmarhus i København og fik besked om, at Rosenkjær indtil videre ikke var sigtet for noget bestemt ud over tyskfjendtlig agitation, og at man var indstillet på, at han skulle løslades inden jul. Den tyske Kriminalrat telefonerede derefter til Kolding arrest for at søge løsladelsen gennemført, men fik af sin kollega at vide, at en løsladelse under ingen omstændigheder kunne komme 
Aage Buhl Rosenkjer

(1890-1944) blev ansat

ved Statsskolen $i$ Tonder $i$

1920. Han var stærkt enga-

geret $i$ ungdomsarbejdet og

var formand for Tonder

Amts Idrætsforening og

desuden medarbejder ved

Det unge Grænsevarn/

Dansk-Nordisk Ungdoms-

forbund. Via terrænsportsforeningerne og Dansk Samling kom han ind $i$ modstandsbevagelsen og var med til at planlægge sabotage. Han blev arresteret af GESTAPO den 11.

december 1943 og deporteret til Neuengamme den 15. september 1944. Han døde to måneder senere $i$ udekommandoen Husum, knap 60 kilometer syd for Tonder, af den umenneskelige behandling $i k z$-lejren. Aage Rosenkjar pd sportspladsen $i$ Tonder $i$ 1930'erne. Foto: Museum Sonderjylland. ISL - Lokalhhstorie.

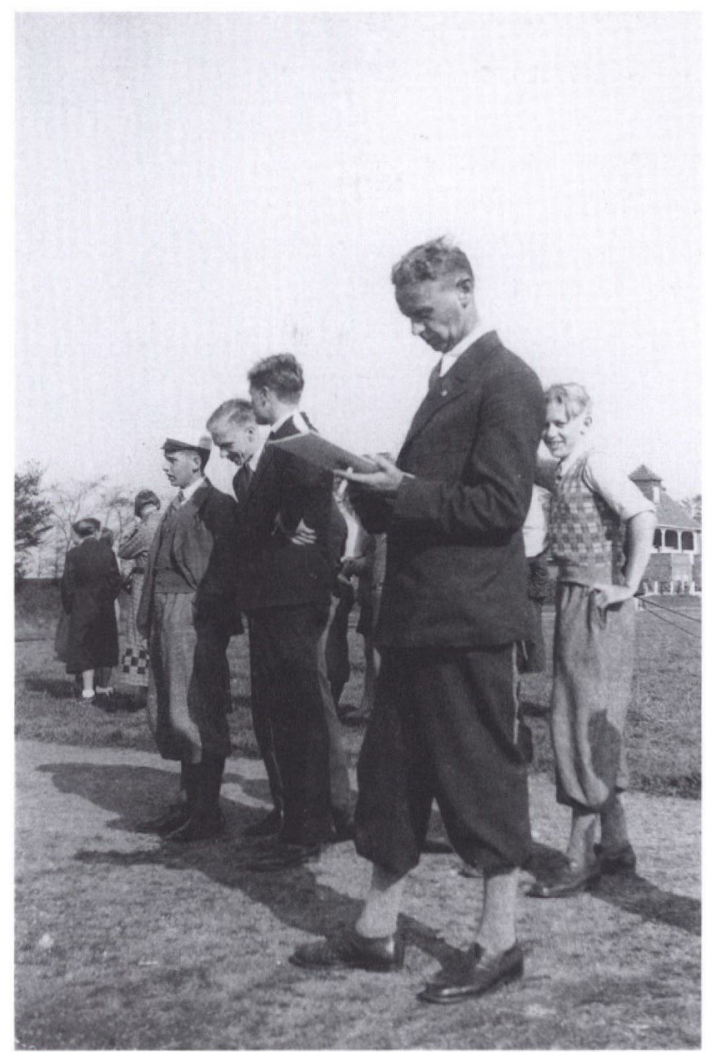

på tale foreløbig, idet Rosenkjær var svært belastet. Samme besked fik statsadvokaten, da han henvendte sig.

En adresse, som var underskrevet af en række fremtrædende personer hovedsagelig fra Tønder by og omegn, bl.a. rektor Randrup, borgmester Paulsen, lensgreve Schack og folketingsmedlem Arnth Jensen, blev den 29. december 1943 af Undervisningsministeriet sendt til Udenrigsministeriet. I adressen omtaltes Rosenkjærs store betydning for Tønder Statsskole, både hvad angik hans lærervirksomhed, hans hverv som inspector og hans store engagement $i$ skolens fritidsaktiviteter, især inden for sport og idræt, og man anmodede indtrængende de tyske myndigheder om, at Rosenkjær hurtigt måtte blive løsladt. Udenrigsministeriet henvendte sig den 7. januar 1944 til Werner Best om sagen, vedlagde adressen og bad ham udvirke, at Rosenkjær blev løsladt. Werner Best svarede den 7. marts 1944, at han havde 
undersøgt sagen, og at Aage Rosenkjær havde tilstået $i$ sit hjem at have opbevaret sprængstof for en person, som var eftersøgt for sabotage, og at det tyske sikkerhedspoliti i øvrigt havde fastslået, at Rosenkjærs hjem havde været opsamlingssted i større stil for sabotagegenstande, af hvilken grund de tyske myndigheder ikke så sig i stand til at foretage sig noget til gunst for Rosenkjær. Rosenkjær blev på et tidspunkt flyttet til Frøslevlejren, og natten mellem den 14. og 15. september 1944 blev han sammen med ca. 200 andre fanger i Frøslevlejren ført til en koncentrationslejr i Husum, en underafdeling af Neuengamme-lejren, hvor gennemsnitslevetiden for en $\mathrm{kz}$-fange var tre måneder. Her døde Aage Rosenkjær den 18. november 1944 af dysenteri, som han havde pådraget sig under de umenneskelige forhold $\mathrm{i}$ lejren. Hans medfange, Hans Mørup, der besøgte ham den sidste aften, før han døde, har berettet om hans sidste stund: "Han ved, han skal dø og tager min hånd, som han knuger med sine sidste kræfter: 'Hans, du skal klare dig. Du skal vende hjem og fortælle verden, hvordan tyskerne har behandlet mennesker. Fortæl dem sandheden, Hans. Du må love mig det.' Jeg nikker, og sammen beder vi Fader Vor.«127

\section{»Drenge-sammensværgelse« i Sønderborg}

Den 4. januar 1943 indberettede Sønderborg Statsskoles rektor, A. Egeberg Jensen, til Undervisningsministeriet, at politiet lige før jul var kommet under vejr med, at der $\mathrm{i}$ byen eksisterede en drenge"sammensværgelse«, som skulle være rettet mod tyskerne. Der havde ikke fundet sabotagehandlinger sted, men politiet havde dog anset sagen for så alvorlig, at man havde foretaget nogle arrestationer, deriblandt af to elever i 3.g. ${ }^{128}$ Den ene af de to gymnasieelever, Olaf, syntes at være primus motor i sammensværgelsen, hvis formål ifølge den anden gymnasieelev, Helmuth, blot var at genere nogle af hjemmetyskerne. De to legede dog kraftigt med ilden, og sagen kunne være endt gruelig galt, fordi politiet igennem en periode tæt overvågede de hen mod 20 drenge, som efterhånden kom med i sammensværgelsen. Bl.a. gennem aflytning af de involverede drenges telefoner fik politiet efterhånden indtryk af en meget alvorlig sag. Men drengene fantaserede kun. Politiet kunne ikke vide, at en »engelsk kontaktperson" med kodenavnet K167 slet ikke eksisterede, men var opdigtet af en af drengene for at imponere kammeraterne - fordi han 


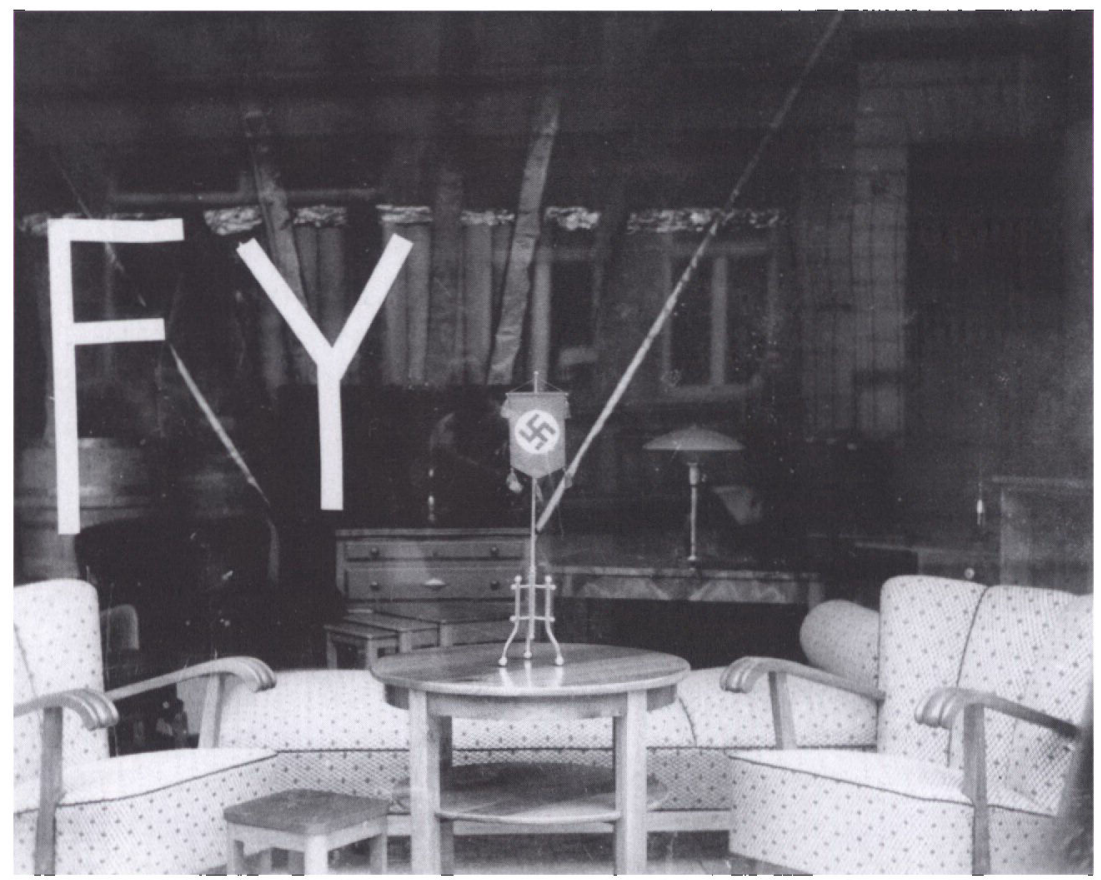

I begyndelsen af 1943 blev en såkaldt "drenge-sammensværgelse " trævlet op $i$ Sønderborg. Det var skole- og gymnasiedrenge, der fantaserede om at "gore noget "mod besættelsesmagten. To 3.g-elever på Sønderborg Statsskole var blandt de arresterede. Allerede $i 1941$ havde der varet "drenge-streger" $i$ Sonderborg. Et udstillingsvindue for "NS-Winterhilfswerk", $i$ hvilket præmien - et dagligstuemoblement - var udstillet, blev bemalet med ordet "fy! « Foto: Rudolf Gimm. Museum Sonderjylland. ISL Lokalhistorie.

syntes, det var "så spændende«. Men da drengene også begyndte at fantasere om at yde hjælp til en forestående - slet ikke planlagt engelsk invasion på Vestkysten, slog politiet til!! ${ }^{129}$

Den 22. januar 1943 var rektor til møde om sagen med undervisningsministeren og departementschef Graae, og her fortalte rektoren, at Olaf stadig var fængslet og rimeligvis ikke ville blive løsladt, før han havde udstået den straf, som han formentlig ville blive idømt. Helmuth var foreløbig blevet løsladt, indtil statsadvokaten for særlige anliggender havde truffet bestemmelse om, hvorvidt der skulle rejses tiltale mod ham eller ej. Undervisningsministeriet gav rektor besked på, at Helmuth ikke måtte deltage i skolens undervisning, før statsadvokaten havde truffet sin afgørelse. 
Den 4. april 1943 skrev rektor til Undervisningsministeriet og gik i forbøn for Helmuth. Rektor havde fået oplysning om, at sagen mod Olaf ville trække ud, og da statsadvokaten havde sagt, at Helmuths skæbne først ville blive afgjort samtidig med afgørelsen af Olafs, ansøgte rektor på trods af ministeriets tidligere afgørelse om tilladelse til at lade Helmuth genoptage sin skoleundervisning, selv om det endnu var uvist, om der ville blive rejst tiltale. Rektor påpegede, at Helmuth på dette tidspunkt havde været væk fra undervisningen i tre måneder, og hvis han ikke snarest fik lov til atter at deltage i undervisningen, ville han ikke få sin studentereksamen i den kommende eksamenstermin. Dette måtte rektor opfatte som en meget hård straf for en forseelse, som dog nok ville vise sig ikke at være særlig betydelig, hvilket efter rektors mening også fremgik af, at drengen på et meget tidligt tidspunkt i sagen var blevet løsladt. Samtidig bad rektor om tilladelse til, at drengens årskarakterer måtte blive fastlagt på grundlag af hans terminskarakterer $\mathrm{i}$ 1. termin. ${ }^{130}$ Ministeriet gik allerede fire dage senere ind på rektors forslag, ${ }^{131}$ og Helmuth blev student $2 \frac{1}{2}$ måned senere. ${ }^{132}$ Olaf blev i foråret 1943 overført til Vestre Fængsel i København, og midt i juli 1943 blev han idømt et halvt års fængsel for tyskfjendtlig virksomhed. Straffen blev dog anset for udstået med varetægtsopholdet, og han blev derfor straks efter domsafsigelsen sat på fri fod. ${ }^{133}$ Den 31. juli $1943 \mathrm{skrev}$ rektor til ministeriet, at Olaf meget ønskede at fortsætte sin skolegang og gå 3.g om, således at han kunne få sin studentereksamen i sommeren 1944. Rektor anførte, at Olafs forseelse havde vist sig kun at bestå i hans medlemskab af en såkaldt "hemmelig klub « samt $i$, at han i sommerferien 1942 på Vestkysten havde drevet en slags spionage, men at han med varetægtsopholdet jo havde betalt for sin brøde. Efter rektors mening var Olaf »en fanatisk, men gennembrav og reel dreng", og han kunne ikke forestille sig, at hans fortsættelse som elev i skolen kunne forårsage vanskeligheder uden for skolens mure. Rektor indstillede derfor til ministeriet, at Olaf fik tilladelse til at fortsætte sin skolegang i Sønderborg Statsskoles 3.g fra det nye skoleårs begyndelse. ${ }^{134}$ Den 12. august 1943 bifaldt ministeriet det ansøgte. ${ }^{135}$ Olaf blev student i sommeren $1944 .^{136}$

\section{Den sidste svære tid}

Den sidste del af besættelsestiden blev svær at komme igennem. Navnlig tyskernes beslaglæggelse af skolerne voldte store problemer. 
Allerede i oktober 1943 beslaglagde den tyske værnemagt Tønder Statsskole og Haderslev Katedralskole. I januar 1945 blev Sønderborg Statsskole beslaglagt, og den følgende måned måtte Aabenraa Statsskole forlade skolebygningerne. Periodevis blev visse fag som sang og gymnastik skåret væk, det sidste dog kun i vinterhalvåret, og skolernes yngste årgange gik ofte $\mathrm{i}$ månedsvis kun $\mathrm{i}$ skole hver anden dag, da det var svært at finde egnede lokaler til undervisningen. Nogle klasser blev undervist i private hjem, f.eks. en klasse i postmesterens dagligstue, en anden i præstens spisestue, en tredje i rektorboligens kælder og en fjerde $i$ et privat firmas lagerbygning. Timerne måtte også afkortes, når lærerne ofte skulle nå fra ét lokale til et andet i den modsatte ende af byen. Hertil kom, at de offentlige transportmidler tit var indstillet, så det var umuligt for de udenbys elever at komme i skole. Disse indskrænkninger og flere til fremkaldte et vist moralsk fordærv hos mange elever samt en mærkbar ligegyldighed over for skolen, hvilket bl.a. gav sig udslag i mange ulovlige forsømmelser. ${ }^{137}$

Allerede i 1941 havde ministeriet pga. de særlige forhold under besættelsen nedsat eksamenspensa til studentereksamen, og fra 1943 havde man tillige nedsat læsepensa. Men ved eksamen i 1945 var det imidlertid nødvendigt med helt ekstraordinære lempelser. Ministeriet gav derfor i september 1944 undervisningsinspektøren bemyndigelse til at indrømme vidtgående dispensationer ved studentereksamen i 1945. Den 24. januar 1945 udsendte undervisningsinspektøren meddelelse om indskrænkninger for hvert enkelt af eksamensfagene. For eksempel skulle der $\mathbf{i}$ faget fysik ved den kommende eksamen kun opgives $1 / 3$ af det krævede pensum, i matematik kun 2/5 af det læste pensum, og for skriftlig matematiks vedkommende blev der nævnt en række discipliner, hvori der ikke måtte stilles opgaver. Derudover fik rektorerne bemyndigelse til at lade den mundtlige eksamen udgå $i$ to af de fag, i hvilke der ikke blev tildelt skolen beskikkede censorer. Ministeriet oplyste samtidig rektorerne om, at der senere i samme eksamenstermin ville blive etableret en ny prøve for de elever, der pga. frihedskampen var fraværende ved den skriftlige eksamen. For elever, der af samme årsag var fraværende $i$ et eller flere mundtlige fag, ville der ligeledes blive arrangeret en ny prøve. Desuden gav ministeriet besked på, at eksaminationen ved den mundtlige eksamen skulle foretages på bredere basis end sædvanligt. Såfremt en elev i et fag, der stillede særlige krav til hukommelsen, viste uventet usikker- 


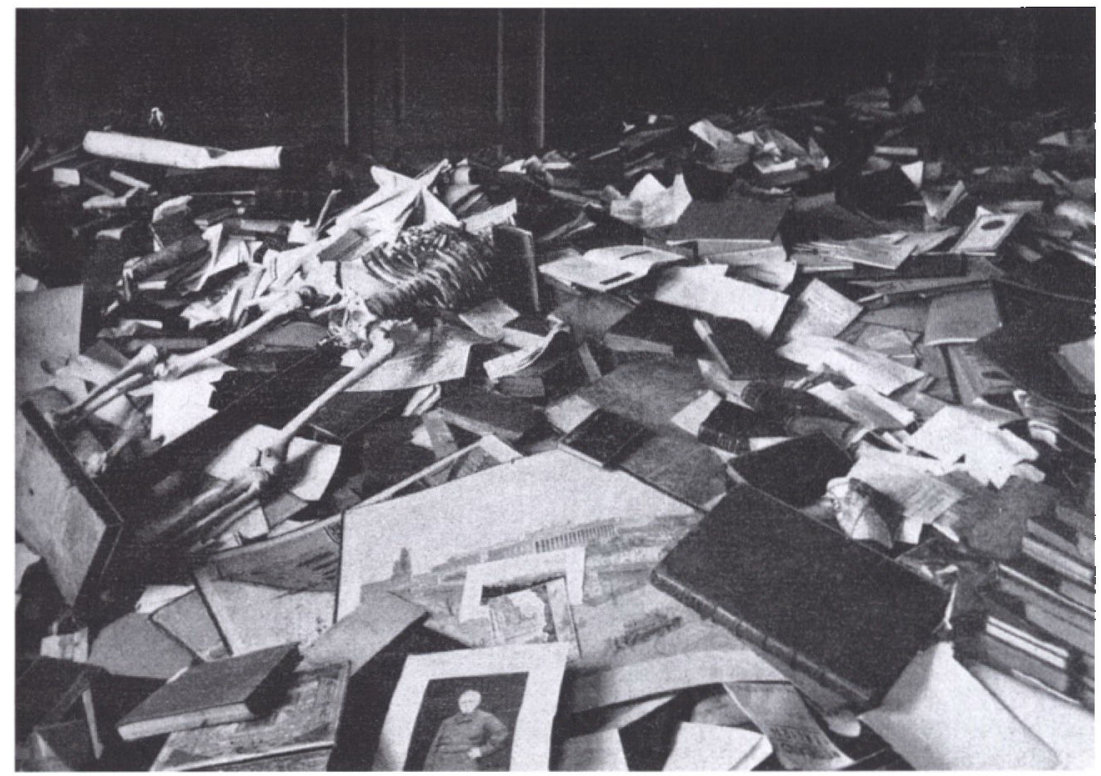

Haderslev Katedralskoles bibliotek, maj 1945. Flere af de sonderjyske gymnasier oplezede at få lokaler eller bygninger beslaglagt til varnemagtsformål - og soldaterne passede ikke altid lige godt på tingene. Biblioteket på Haderslev Katedralskole var $i$ sørgelig forfatning, da soldaterne var draget bort: Bøger lå i én stor bunke, og soldaterne har tilsyneladende moret sig med at smide anatomi-undervisningens skelet øverst på bunken. Foto: Haderslev-Samfundets Arsskrift 1945/46.

hed i det stillede eksamensspørgsmål, skulle der gives vedkommende et andet spørgsmål. I øvrigt pointerede ministeriet, at fastsættelse af eksamenskarakterer ved så vel mundtlige som skriftlige prøver skulle ske under rimelig hensyntagen til elevernes årskarakterer, som altid skulle forelægges censor og benyttes som udgangspunkt. ${ }^{138}$

\section{Afslutning}

De sønderjyske gymnasieskoler begyndte deres gerning i 1920 lige efter en krig. Da de i 1945 kunne fejre 25-årsdagen, skete det også lige efter en krig. Men så hører ligheden også op! I 1920 var der forståelsespolitik i Folkeforbundets ånd, forsoning mellem dansk og tysk og håb om fredeligt samliv mellem de to nationaliteter. I 1945 var der vrede over illoyalitet og harme over alle de brudte løfter. Forsoning mellem dansk og tysk var noget, der var skudt ud i en fjern og ganske uvis fremtid.

I 1920 var der glæde over de mange muligheder i det genvundne 
danske land. I 1945 måtte man sande, at de mange muligheder fra Genforeningen var blevet forspildt, og det gjorde ondt. I 1920 var man overbevist om, at freden, roen og stabiliteten fra for 1 . verdenskrig ville vende tilbage. I 1945 måtte man se i øjnene, at de rolige dage aldrig nogensinde ville blive til virkelighed igen. Men ikke kun i 1920, men også i 1945 håbede man trods alt på, at menneskelige idealer i sidste ende ville sejre. ${ }^{139}$

Sønderborg Statsskoles rektor, humanisten Andreas Egeberg Jensen, var ikke uventet en af dem, der manede til overbærenhed og besindighed, da frihedens time i 1945 oprandt. Han var sikker på, at det ville tjene fremtiden bedst. "Jeg har altid syntes, at hævn er en plebejerfølelse«, sagde han, ${ }^{140}$ og han så, at en af de gode ting ved besættelsesårene var, at de havde drevet det gamle land og Sønderjylland tættere sammen. "Nazismen har gjort os den kæmpetjeneste at få os til at glemme småting, der skiller «. ${ }^{141}$ Og daværende adjunkt, senere lektor, ved Haderslev Katedralskole, Magnus Favrholdt, fastslog, at krigsårene havde fået lærerkollegiet til at rykke tættere sammen og "har vor tid ikke lært os meget godt, har vi i hvert fald fået lært, at ensretning kan have de uhyggeligste følger. «142

\section{LITTERATUR OG KILDER}

\section{Upubliceret materiale}

\section{RIGSARKIVET (RA)}

Statsadwokaten for særlige anliggender (SSA):

A.S.-sag 4/88; A.S.-sag 68/11; A.S.-sag 68/119; A.S.-sag 69/15; A.S.-sag 69/ 108; A.S.-sag 69/136; A.S.-sag 71/1; A.S.-sag 71/197; A.S.-sag 71/248; U.K. 1358.

\section{Underoisningsministeriets arkiv}

(UVM):

Undervisningsinsp. for gymnasieskolerne: Kopibog 1918-1920; Korrespondance 1940; Korrespondance 1942.

Undervisningsministeriet 1. dept.: 1. kt. Jo 28-2/1942.

Undervisningsministeriet 1 . dept.: 2 . kt. Jo 204/1941; Jo 453/1942; Jo 695/1943; Jo 342/1945; Jo 553/1945
Undervisningsministeriet 2. dept.: 1 . kt. Jo 459/1930; Jo 629/1933; Jo 180/1923; Jo 633/1933; Jo 825/1936; Jo 142/1939; Jo 765/1939; Jo 315/ 1940; Jo 354/1940; Jo 367/1940; Jo180/1941; Jo 279/1941; Jo 285/ 1941; Jo 143/1942; Jo 116/1943; Brev 7900-01/1943; Brev 17278-79/1943

Undervisningsmin. Gymnasieafdelingen: Jo 40-28-01-35-02/1975

Undervisningsmin. Gruppeordnede sager. Ansøgningsprotokoller for embeder under Undervisningsministeriet 1913-1957

Udenrigsministeriets arkiv 1909-1945 (UM):

7.X.9.a., Pk H7-257; 7.X.9.b. Pk H7260; P.J.I. Jo 5.D.29.b; 84.C.55a; 84.C.55b; 84.G.5.204; 84.G.5.286a; 84.G.5.286c. 
Udenrigsministeriets Pressebureau

(UMP)

1940 H 109.C.4. Aktpakke I

\section{LANDSARKIVET FOR SØNDERJYL-}

LAND (LAA)

Sønderborg Statsskoles arkiv

Rektors journal over afgåede skrivelser 1941-1950.

Rektors dagbog 1938-1960.

Tender Statsskoles arkiv

N4-1, C-1. Krigen 1940-45.

\section{LOKALHISTORISK ARKIV FOR}

TØNDER KOMMUNE (LAT)

A. Egeberg Jensens privatarkiv

Skoletaler i Haderslev 1939-41.

Dimissionstale. Sonderborg Statsskole 1946.

\section{AVISER OG TIDSSKRIFTER}

Flensburger Nachrichten

Hejmdal

Junge Front

Hamburger Fremdenblatt

Nordschleswigsche Zeitung

Schleswig-Holsteinische Tageszeitung

\section{Litteratur}

Inge Adriansen: Sindelagskamp, national samling og legal modstand. I: Inge Adriansen og Henrik Skov Kristensen: Als og Sundeved 1940-45. Historisk Samfund for Als og Sundeved, 1995.

Steen Andersen: "Departementschefstyret $\propto$. I: Gads leksikon om dansk besættelsestid 1940-45. København 2002.

A. Barfod: Departementschefsstyret i Danmark fra 29. august 1943 til 4. maj 1945. I: Nordisk Administrativt Tidsskrift 1945.

Bilag til Den parlamentariske Kommissions beretning til Folketinget, bd. 11 og bd. 14 . Kobenhavn 1953

Georg Buchreitz: Sonderjysk Skolevæsen i Øjeblikket. Månedsskriftet »Tilskueren«, Årg. 1933.

Georg Buchreitz: "Lektor Viggo Rosent in memoriam “. Aabenraa Statsskoles årsskrift 1946.
Georg Buchreitz: Skolen under besættelsen. I: Johs. Brøndsted \& Knud Gedde (red.): De fem lange år. Danmark under Besættelsen 1940-1945, bd. 3. Kabenhavn, 1947.

Jes Peter Caspersen: Sønderjylland i 1920 'erne og 30'erne. Aabenraa Rotary Klub. 1998.

Claus Eskildsen: Det tyske mindretal under besættelsen. I: Chr. Refslund: "Fem år. Indtryk og oplevelser «, bd. 2. Kobenhavn, 1945.

M. Favrholdt: Haderslev Latinskoles historie 1567-1967. Haderslev, 1966.

Folketingstidende 1939.

Aage Friis (red.): Danmark under verdenskrig og besættelse. Historiske enkeltfremstillinger. Odense, 1946.

Frit Danmarks Hvidbog. Besættelsestiden i dokumenter og kommentarer. København, 1945.

Kjeld Galster: Den danske gymnasieskole. I: „Fem år. Indtryk og oplevelser«, bd $1+2$. Kobenhavn, 1946.

Haderslev Katedralskoles årsskrifter 1943-1945.

Haderslev Katedralskole 1920-1970. Jubilæumsskrift. Haderslev, 1972.

Hans Heinrich Hansen: Brobyggere i grænselandet. Kronik i Berlingske Tidende 23. april 2002.

Harry Haue m.fl.: Kvalitetens vogter. Statens tilsyn med gymnasieskolerne 1848-1998. Undervisningsministeriet 1998.

Hans Hertel: Skole og undervisning. I: Gads leksikon om dansk besættelsestid 1940-45. Kobenhavn, 2002.

Johan Hvidtfeldt og Peter Kr. Iversen: Aabenraa bys Historie III. Aabenraa, 1974.

Jørgen Hæstrup: "...Til landets bedste Hovedtræk af departementschefsstyrets virke 1943-1945. København, 1966.

A.C. Højberg Christensen: Skolen. I: Aage Friis (red.): Danmark under verdenskrig og besættelse. Historiske enkeltfremstillinger, bind IV. Odense, 1946.

Franz v. Jessen: Haandbog i det slesvigske Sprrgsmaals Historie 19001937 I-III. Kobenhavn, 1938.

Hågen Kiil: Rektor A. Egeberg Jensens foredragsmanuskripter. I: Sonderjysk Mănedsskrift 1990. 
Hans Kirchhoff m. fl. (red.): Gads leksikon om dansk besættelsestid 19401945. København, 2002.

Tage Kaarsted: De danske ministerier 1929-1953 III. København, 1977.

John T. Lauridsen: Frits Clausen. I: Gads leksikon om dansk besættelsestid 1940-1945. København, 2002.

Hans Mørup: På fløjen. En sønderjysk stridsmands erindringer fra kulturog modstandskamp 1929-1945. Aabenraa, 2000.

Ellen Nørgaard: Skolebogsbetænkningens historieafsnit - Dets tilblivelseshistorie og træk af dets modtagelse. I: Årbog for dansk Skolehistorie 1970.

Henning Poulsen: Besættelsesmagten og de danske nazister. København, 1970.

Henning Rohde: Noget lykkedes... Erindringer. Kobenhavn, 1994.

J.E. Schau: Skolen og Modstandsbevægelsen. I: Haderslev-Samfundets Aarsskrift 1945.

Hans Schultz Hansen og Henrik Skov Kristensen (red.): Sonderjylland under krig og besættelse 1940-1945. Aabenraa, 2003.

Kaj Sieverts: Da de kom til Tønder. I: Chr. Refslund: »Fem år. Indtryk og oplevelser", Kobenhavn, 1945.

A. Svensson: Dansk Samråd. Et bidrag til sønderjysk historie før og under den tyske besættelse. I: Sønderjydske Årbøger 1951.

Sønderborg Statsskoles årsskrifter 1940-1945.

Sønderborg Statsskole 1920-1945. Festskrift udgivet af Sønderborg Samfundet 1945.

Sonderborg Statsskole 1920-1970. Jubilæumsskrift, Udgivet af Sonderborg Samfundet. 1970.

Kaj Sørensen: Rektor A. Egeberg Jensen - En sønderjysk skolemand. Sønderjyske årbøger, 2001, s. 221242.

Kaj Sørensen: Ordningen af det højere skolevæesen i Sonderjylland 19181920. Sønderjyske årbøger, 2003, s. 83-118.

Tønder Statsskoles årsskrifter 19401945.

Tonder Statsskole 1920-1945. Jubilæumsskrift. Tønder, 1945.

A.J. West: Fra det genvundne Land. Kobenhavn, 1924.

Aabenraa Statsskoles årsskrifter 19401945.

Aabenraa Statsskole 1920-1945. Jubilæumsskrift. Aabenraa, 1945.

Aabenraa Statsskole 1920-1970. Jubilæumsskrift. Udgivet af Aabenraa Statsskoles Samfund, 1971.

\section{NOTER}

1. Om tilrettelæggelsesarbejdet se: Kaj Sørensen, 2003.

2. RA, UVM, Undervisningsinspektionen for gymnasieskolerne. Kopibog 1918-1920. Skrivelse nr. 280.

3. v. Jessen, III, s. 154.

4. West, 1924 , s. $30 \mathrm{f}$.

5. v. Jessen, III, s. 156. Sonderborg Statsskole 1920-1945, s. 51.

6. Friis, 1946, bd. IV, s. 7.

7. Caspersen, 1998, s. 11 og 15.

8. Buchreitz, 1933, s. 392.

9. Hans Heinrich Hansen, 2002. Om Hitlers tanker om en nærmere tilknytning mellem Tyskland og andre germanske lande i 1920'erne og 1930'erne se Poulsen, 1970, s. 128-152.
10. Det tyske udenrigsministerium tillagde ikke de tysk-danske mindretalssporgsmål stor betydning, og der var heller ikke under krigen seriøse planer om at kræve Nordslesvig tilbage til Tyskland.

11. Parlamentariske Kommission, bd. 14 , s. 72.

12. RA, SSA, A.S.-sag 68/11.

13. RA, UM, 7.X.9.A. Pk. H7-257. Brev af 9/9-1933 fra Udenrigsministeriet til Undervisningsministeriet.

14. RA, UVM, Underv.min. 2. dept 1. kt. Jo $633 / 1933$. Brev af $10 / 10$ 1933 fra amtsskoledirektør Nicolai Svendsen til Undervisningsministeriet. 
15. RA, SSA, A.S.-sag 69/15. Indberetning af 3. februar 1941 fra Politimesteren i Sonderborg. LAA, Sønderborg Statsskole: Rektors journal over afgåede skrivelser 1941-1950. Skrivelse til Underv.min. 23. august 1941 .

16. Aabenraa Statsskole 1920-1945, s. 87.

17. Schau, 1945 , s. $30 f$.

18. RA, UVM, Underv.min. 2. dept. 1. kt. Jo 142/1939. Indberetning til departementschef Fr. Graae fra Viggo Rosent 26. december 1938.

19. Ibid.

20. Flensburger Nachrichten 9.11 . 1938. RA, UM, P.J.I. Jo 5.D.29.b, udklip.

21. RA, UVM, Underv.min. 2. dept. 1. kt. Jo 142/1939. Brev af 7. december 1938 fra Jep Schmidt til Jørgen Jørgensen.

22. Folketingstidende 1939 spalte $384 \mathrm{f}$. $+397$.

23. RA, UVM, Underv.min. 2. dept. 1. kt. Jo 142/1939. Udateret skrivelse juli 1939 fra Undervisningsministeriet til lektor Viggo Rosent.

24. Se f.eks. Schleswig-Holsteinische Tageszeitung 20. juli 1939.

25. Buchreitz, 1946.

26. RA, UVM, Underv.min. 2. dept. 1. kt. Jo 142/1939. Undervisningsinspektøren for Gymnasieskolerne. Korrespondance 1940.

27. Parlamentariske Kommission, bd. 14, s. 114. Optegnelser om overfaldet på lektor Viggo Rosent.

28. Parlamentariske Kommission, bd. 14, s. 114. Forhør af Jep Schmidt 15. februar 1949.

29. Parlamentariske Kommission, bd. 14, s. 112. Indberetning til Det tyske Gesandtskab i København den 22/12-1941.

30. Parlamentariske Kommission, bd. 14 s. $112 \mathrm{ff}$. Droftelser den 6., 7. og 10. januar 1942 angående overfaldet på Rosent.

31. Parlamentariske Kommission, bd. 14 , s. 114. Meddelelse fra Udenrigsministeriet.

32. "Hejmdal « 16. februar 1943. Parlamentariske Kommission, bd. 14, s. 149. Telegram fra det tyske møde i
Haderslev 14. februar 1943 til stats- og udenrigsminister Erik Scavenius. Ibid, s. 753., aktstk. 107, Referat af Jens Møllers tale.

33. Parlamentariske Kommission, bd. 14 , s. 155 , note 2 . Referat af modet mellem Scavenius og Jens Møller 17/2-1943.

34. Se Sdj.Årb. 2002, s. 199-226 og Sdj.Årb. 1995, s. 363-413.

35. Parlamentariske Kommission, bd. 14 s. 153ff. Brev af 3/3-1943 fra Jens Møller til Udenrigsministeriet.

36. RA, UVM, Underv.min. 2. dept. 1. kt. Jo 367/1940. Brev af 17. februar 1943 fra Aabenraa Statsskoles rektor til Undervisningsministeriet.

37. Rohde, 1994, s. 87 . Sieverts, 1945 , s. 82. Eskildsen, 1945, s. 131.

38. Aabenraa Statsskole 1920-1945, s. $74 \mathrm{f}$.

39. LAT, A. Egeberg Jensens privatarkiv, Pk. 11. Skoletaler i Haderslev 1939-41.

40. LAA, Sonderborg Statsskoles arkiv. Rektors dagbog 1938-1960.

41. Tønder Statsskole 1920-1945, s. 50.

42. RA, UVM, Underv.min. 2. dept. 1. kt. Jo 315/1940, skrivelse af 14/41940 fra Rektor Randrup til Undervisningsministeriet.

43. Ibid + Sieverts, 1945 , s. 84 .

44. Haue, 1998, s. 229.

45. Kaarsted, bd. Ill s. 203.

46. Haue, 1998 , s. 229. Barfod, 1945, s. 115. Hans Kirchhoff, 2002, s. 107.

47. A.C. Højberg Christensen, 1946, s. $27 \mathrm{f}$.

48. http://www.waffen-ss.no/ Regiment-Nordland-English.htm.

49. RA, UVM, Underv.min. 1. dept. 2. kt. Jo 204/1941.

50. RA, UVM, Underv.min. 1. dept. 2. kt. Jo $453 / 1942$.

51. RA, SSA, A.S.-sag 71/1. Politimesteren i Tønder Kobstad, optegnelser pr. 12. september 1940 til statsadvokaten for særlige anliggender.

52. RA, UVM, Underv.min. 2. dept. 1. kt. Jo 354/1940. Skrivelse af 20/51940 fra rektor Randrup til Undervisningsministeriet. Underv.min. 2. dept 1. kt. Jo 354/1940, skrivelse af 10/6-1940 fra Undervisnings- 
ministeriet til rektor for Kolding højere Almenskole.

53. Aabenraa Statsskole 1920-1945, s. $75 f$.

54. LAT, A. Egeberg Jensens privatarkiv, $\mathrm{Pk}$ 11. Skoletaler Haderslev 1939-1944.

55. Aabenraa Statsskole 1920-1945 s. $76 f$.

56. Sønderborg Statsskole 1920-1945, s. 34. Sonderborg Statsskole 19201970 s. 48.

57. Schultz Hansen og Skov Kristensen, 2003, s. 50. Svensson, 1951, s. 47.

58. RA, UMP, H 109 C 4 Aktpakke I 1940. Tønder Statsskole, s. 51f.

59. RA, UVM, Undervisningsministeriet. 2. dept. 1. kt. Jo $367 / 1940$. Brev af 5.2.1941 fra Aabenraa Statsskoles rektor.

60. RA, UVM. Gruppeordnede sager. Ansøgningsprotokoller for embeder under Undervisningsministeriet 1913-1957.

61. RA, UVM, Undervisningsministeriet 2. dept. 1. kt. Jo 279/1941. Udateret indberetning juni $1941 \mathrm{fra}$ undervisningsinspekteren for gymnasieskolerne til Undervisningsministeriet.

62. RA, UVM, Undervisningsmininisteriet 2. dept. 1. kt. Jo 279/1941. Officiel meddelelse fra juni 1941 om ministeriets udnævnelse af $\mathrm{Ge}$ org Buchreitz som rektor for Aabenraa Statsskole pr. 1/8-1941.

63. RA, UVM, Undervisningsinspektøren for gymnasieskolerne. Korrespondance 1940 . Brev af $8 / 10$ 1940 fra rektor Svend Bruun, Slagelse kommunale højere Almenskole. Se også Hejmdal 27/6-1933.

64. RA, UVM, Undervisningsministeriet. Gymnasieafdelingen. Jo 4028-01-35-02/1975. Udateret brev fra Udenrigsministeriets Pressebureau til Udenrigsministeriet.

65. RA, UM. 7.X.9a. Bladudklip.

66. RA, UVM, Undervisningsministeriet. Gymnasieafdelingen. Jo 4028-01-35-02/1975. Udateret brev fra Undervisningsministeriet til Udenrigsministeriet februar 1942.
67. RA, UM. H.84.C.55b, Adler Lund. Lektor v. Senderborg Statsskole.

68. Galster, 1945, bd. 1, s. 112.

69. Cirkulære af 18. juni 1941 til rektorerne for statens højere almenskoler angående demonstrationer.

70. Cirkulærskrivelse af 23. februar 1942 til rektorerne for de offentlige højere almenskoler angående indskriden mod evt. upassende opførsel fra skoleelevers side over for kredse af kammerater m.v.

71. Cirkulære af 12 december 1942 til rektorerne for statens højere almenskoler angående kontrol med skoleblades indhold.

72. Cirkulære af 27. januar 1943 til rektorerne for gymnasieskolerne angående demonstrationer mod besættelsesmagten.

73. Buchreitz, 1947, s. 1156.

74. Aabenraa Statsskole 1920-1945, s. 88.

75. RA, SSA, A.S.-sag 69/15. Indberetning af 3. februar 1941 fra Politimesteren i Sønderborg om nationale problemer i byen. Sonderborg Statsskole 1920-1970, s. 49.

76. RA, SSA, A.S.-sag 69/15. Brev af 19. februar 1941 fra Statsadvokaten i Sonderborg til Statsadvokaten for særlige anliggender.

77. RA, UVM, Underv.min. 2. dept. 1. kt. Jo 180/1923. Rektor Hertz' påtegning på Adler Lunds ansøgning af 11/1-1923.

78. RA, UVM, Underv.min. 2. dept. 1. kt. Jo 285/1941. Skrivelse af 3. april 1941 fra rektor A.J. West til undervisningsinspektøren for gymnasieskolerne.

79. RA, UVM, Underv.min. 2. dept. 1. kt. Jo 285/1941. Brev af 29. maj 1941 fra O.C. Mohr til Fr. Graae. Brevet er aftrykt i i Frit Danmarks Hvidbog, bd. I s. 306.

80. RA, UVM, Underv.min. 2. dept 1. kt. Jo 285/1941. Klage af 26. maj 1941 til Udenrigsministeriet fra Renthe-Fink over anti-tyske bemærkninger i Adler Lunds historieundervisning.

81. RA, UVM, Underv.min. 2. dept. 1. kt. Jo 285/1941. Skrivelse af 26/9- 
1941 fra Undervisningsministeriet til Adler Lund om pr. 1/10-1941 at gøre tieneste ved Roskilde Katedralskole. Sønderborg Statsskole 1920-1970, s. 50. Frit Danmarks Hvidbog, bd. I, s. $305 \mathrm{f}$.

82. RA, UM. H.84.C.55b. Adler Lund. Lektor v. Sønderborg Statsskole. Skrivelse af 8/10-1942 fra Udenrigsministeriet til Justitsministeriet med anmodning om at rejse tiltale mod lektor Adler Lund.

83. RA, UVM, Underv.min. 2. dept. 1. kt. Jo 285/1941. Skrivelse af 10/101942 fra Undervisningsministeriet til lektor Adler Lund. RA, SSA, A.S.-sag 4/88. Udskrift af Dombogen for straffesager for Roskilde Kabstad m.v. 28/12-1942.

84. Et eksemplar af bogen befinder sig på Det kgl. Bibliotek.

85. RA, UVM, Underv.min. 2. dept. 1. kt. Jo 285/1941. Referat af Undervisningsministeriets øverste embedsmænds forhandlinger vedrørende Adler Lunds fortsatte virke ved gymnasieskolerne. Skrivelse af 13/5-1943 fra Undervisningsministeren til Adler Lund. Frit Danmarks Hvidbog, bd. I, s. 307f.

86. RA, SSA. A.S.-sag 69/136, Udateret velkomstadresse til Adler Lund.

87. RA, SSA. A.S.-sag 69/136; A.S.-sag 4/88. Roskilde Politis rapport XXII.L.3/43 af 3/7-1943 om afhøring af Adler Lund.

88. RA, SSA. A.S.-sag 69/136, Sønderborg Politis rapport 701/43 af 14 . juli 1943 om afhøring af elever fra Sonderborg.

89. RA, Se note 83.

90. RA, UVM, Underv.min. 2. dept. 1. kt., Jo 285/1941. Undervisningsinspektorens beklagelse af 7 . april 1941 til ministeriet over West. Brev af 3. april 1941 fra rektor West til undervisningsinspektøren.

91. RA, UVM, Underv.min. 2. dept. 1. kt. Jo 180/1941. Ansøgning af 15. marts 1941 fra rektor A.J. West.

92. Kaj Sørensen, 2001, s. 235ff.
93. RA, UVM, Underv.min. 2. dept. 1. kt. Jo 180/1941. Undervisningsinspektørens skrivelse af 15 . april 1941 til ministeriet.

94. RA; UM. H.84.C.55b. Adler Lund. Referat af møde i UM 29/5-1941.

95. Højberg Christensen, 1946, s. 19 $+61 \mathrm{f}$.

96. Norgaard, 1970, s. 89.

97. Højberg Christensen, 1946, s. 19 $+61 \mathrm{f}$.

98. Ludvig Schmidt var overlærer på Horsens Statsskole og døde i 1915, og West reviderede samtlige udgaver af lærebogen fra og med 2. udgave fra 1918 til og med 7. udgave.

99. RA, UVM, Underv.min. 2. dept. 1. kt. Jo $459 / 1930,629 / 1933,765 /$ 1939 og 143/1942. Højberg Christensen, 1946 , s. $19+61 \mathrm{f}$.

100. Galster, 1946, bd. 2. s. 159.

101. Højberg Christensen, 1946, s. 27.

102. http://ingeb.org/garb/ Imarleen.html. Lili Marleen var meget populær blandt soldater i 2 . verdenskrig. Melodien er skrevet af Norbert Schultze i 1938.

103. RA, UVM, Undervisningsinspektøren for gymnasieskolerne. Korrespondance 1942. Indberetning af 28. januar 1942 fra rektor Georg Buchreitz, Aabenraa Statsskole.

104. RA, UVM, Underv.min. 1. dept. 1. kt. Jo 28-2/1942. Skrivelse af 28. april 1942 fra rektor Georg Buchreitz til undervisningsinspektøren.

105. RA, UM. 84. C.55a. Brev af 17 . februar 1942 fra Udenrigsministeriet til Undervisningsministeriets 1 . dept. 1. kt.

106. RA, UM. 84. C.55a. Brev til Udenrigsministeriet af 3 . september 1942 fra Undervisningsminister Jørgen Jørgensen.

107. Barfod, 1945, s. 103, 106. Hæstrup, 1966, bd. 1, s. 9.

108. Buchreitz, 1947, s. 1140.

109. RA, UVM, Underv.min. 2. dept. 1. kt. Jo 116/1943. Skrivelse af 13/ 9-1943 fra kons. rektor P. Gjøng, Aabenraa Statsskole, til Undervisningsministeriet. 
110. Redegørelsen kom senere med enkelte tilføjelser og ændringer med i Buchreitz' bog "Spejlinger", som Aabenraa Statsskoles Elevsamfund udgav i 1975, og som også indeholder mange af Georg Buchreitz' skoletaler.

111. Buchreitz, 1947, s. 1140.

112. Højberg Christensen, 1946, s. 63.

113. RA, SSA. A.S.-sag 68/119. Indberetning af 3 . december 1942 fra politimesteren i Aabenraa.

114. RA, SSA. A.S.-sag 71/197. Indberetning af 7 . august 1943 fra politimesteren $\mathrm{i}$ Tonder.

115. Højberg Christensen, 1946, s. 63.

116. Ibid.

117. RA, UM, 84.C.55a. Fortroligt cirkulære af 8 . november 1943 fra Undervisningsministeriet til rektorerne for statens højere almenskoler og Sorø Akademis Skole.

118. Ibid.

119. RA, UM, 84.C.55a. Skriftlig henvendelse af 12/11-1943 fra rektorerne til Undervisningsministeriet vedrørende cirkulære af 8/111943.

120. Sst. Højberg Christensen, 1946, s. 68.

121. RA, UM, 84.C.55a. Skriftlig henvendelse af 2/12-1943 fra Gymnasieskolernes Lærerforening (GL) til Udenrigsministeriet.

122. Højberg Christensen, 1946, s. 69. Hertel, 2002, s. 418.

123. Schau, 1945 , s. $30 \mathrm{f}$.

124. RA, UM, 84.G.5.286a. 84.G.5.286c.

125. Favrholdt, 1966, s. $284 f$.

126. RA, UVM, Underv.min. 1. dept. 2. kt. Jo 342/1945. Skrivelse af 13/ 4-1945 fra Haderslev Katedralskoles konstituerede rektor til Undervisningsministeriet.

127. LAA, Tønder Statsskoles arkiv. N4-1. C-1 »Rosenkjærs fængsling “. RA, UM. 84.G.5.204. Diverse skrivelser vedr. Rosenkjærs fængsling. A.S.-sag 71/248. Indberetning af 9/1-1944 fra politimesteren i Tønder om Rosenkjærs arrestation. UVM Underv.min. 1. dept. 2. kt. Jo 695/1943. Rosenkjærs fængsling. Tønder Statssko- le 1920-1945 s. 54ff. Mørup, 2000, s. 391.

128. LAA, Sonderborg Statsskole. Rektors journal over afgåede skrivelser 1941-1950. Skrivelse af 4/11943 fra rektor til Undervisningsministeriet om en mod tyskerne rettet drenge»sammensværgelse «.

129. RA, SSA, A.S.-sag 69/108. Indberetning af 5/1-1943 fra Sønderborg poltitmester vedr. arrestation af medlemmerne af en drenge»sammensværgelse «. U.K. 1358. Udskrift af Retsbogen for Københavns Byrets afdeling 10.A vedr. sag nr. St. 11/1943 af 30/61943, Anklagemyndigheden mod Olaf Johannsen m.fl.

130. LAA, Sonderborg Statsskole. Rektors journal over afgåede skrivelser 1941-1950. Skrivelse af 4/41943 til Undervisningsministeriet.

131. RA, UVM, Underv.min. 2.dept. 1. kt. Brev $7900-01 / 1943$ af $8 / 4$ 1943 til Sonderborg Statsskoles rektor fra Undervisningsministeriet.

132. Sønderborg Statsskole 1920-1970, s. 201.

133. RA, SSA, A.S.-sag 69/108. U.K. 1358. Udskrift af Retsbogen for Københavns Byrets afdeling 10.A vedr. sag nr. St. 11/1943 af 30/61943, Anklagemyndigheden mod Olaf Johannsen m.fl. LAA, Sønderborg Statsskole. Rektors journal over afgåede skrivelser 19411950. Skrivelse af 20/7-1943 til Undervisningsministeriet med oplysning om dommen over Olaf Johannsen.

134. LAA, Sonderborg Statsskole. Rektors journal over afgåede skrivelser 1941-1950. Skrivelse af 31/71943 til Undervisningsministeriet med anmodning om, at Olaf Johannsen făr lov til at genoptage sin skoleundervisning i $3 g$ fra det nye skoleårs start.

135. RA, UVM, Underv.min. 2.dept. 1. kt. Brev 17278-79/1943 af 12/81943 til Sønderborg Statsskoles rektor fra Undervisningsministeriet med tilladelse til, at Olaf Johannsen genoptager sin sko- 
leundervisning i $3 g$ fra det nye skoleårs begyndelse.

136. Sonderborg Statsskole 1920-1970, s. 206.

137. RA, UVM, Underv.min. 1. dept. 2. kt. Jo 553/1945. Korrespondance mellem de fire gymnasieskoler og ministeriet vedr. gennemførelse af undervisningen under beslaglæggelserne af skolerne. Skolernes årsskrifter 1943/44 og 1944/ 45 samt skolernes jubilæumsskrifter 1920-1945 og 1920-1970.
138. LAA, Haderslev Katedralskoles arkiv. D7. Korrespondance. Tryksager m.v. med historisk materiale. Skolernes årsskrifter 1943/44 og 1944/45 samt skolernes jubilæumsskrifter 1920-1945 og 19201970.

139. Buchreitz, 1945, s. 93.

140. LAT, A. Egeberg Jensens privatarkiv. Dimissionstale. Sønderborg Statsskole 1946.

141. Kiil, Sdj.Mån. 1990, s. 294.

142. Favrholdt, 1966, s. $288+292$. 